\title{
Two new genera and two new species of proteocephalidean tapeworms (Eucestoda) from reptiles and amphibians in Australia
}

\author{
Sophie de Chambrier and Alain de Chambrier
}

Natural History Museum, Department of Invertebrates, P.O. Box 6434, CH-1211 Geneva 6, Switzerland

\begin{abstract}
The examination of the type series of Ophiotaenia gallardi (Johnston, 1911) (syn. Proteocephalus gallardi Johnston, 1911) revealed that it is a mixture of two species of different genera. Lectotype of Ophiotaenia gallardi is designated and the species is redescribed on the basis of it, conspecific paralectotypes and additional materials. The remaining part of the type series belongs to Vandiermenia gen. n. (Acanthotaeniinae), with $V$. beveridgei sp. $n$. as the type- and only species. The new genus differs from all other acanthotaeniine genera, i.e. Rostellotaenia Freze, 1963, Acanthotaenia von Linstow, 1903 and Kapsulotaenia Freze, 1963, by the presence of cortical uterine stem and paramuscular vitelline follicles, particular structure of the internal longitudinal musculature (absent laterally and more developed than in the three above-mentioned genera) and testes limited in two fields separated medially. Type series of Ophiotaenia mjobergi (Nybelin, 1917) (syn. Crepidobothrium mjobergi Nybelin, 1917), O. amphiboluri (Nybelin, 1917) (syn. Crepidobothrium amphiboluri Nybelin, 1917), O. striata (Johnston, 1914) (syn. Acanthotaenia striata Johnston, 1914) and O. longmani Johnston, 1916 are revised and compared with Ophiotaenia gallardi. Australotaenia hylae (Johnston, 1912) comb. n. is proposed for Ophiotaenia hylae Johnston, 1912. Australotaenia gen. n. differs from the remaining genera of the subfamily Acanthotaeniinae by (1) the Type 2 of the formation of the uterus (sensu de Chambrier et al. 2004) (all the other acanthotaeniines have the Type 1 of uterine development), (2) the cortical position of the uterine stem (all the other genera have medullary uterine stem) and (3) the morphology of the internal longitudinal musculature, which is composed of few well-developed bundles of fibres (in contrast to the other genera). The new genus also differs from Vandiermenia by eggs not in clusters, the presence of two testicular fields (versus one in Vandiermenia) and the structure of the longitudinal internal musculature with only 8-10 bundles (versus formed by numerous bundles and with the presence of secondary muscles in Vandiermenia). Ophiotaenia sp. sensu de Chambrier (2004), a parasite of Litoria moorei, is described as Australotaenia grobeli sp. n., which can be distinguished from Australotaenia hylae by the smaller number of testes (46-76 versus 74-106), greater cirrus-sac length/width of proglottis ratio (27-33\% versus $17-19 \%)$ and the smaller ovary width / proglottis width ratio (55-63\% versus $68-71 \%)$.
\end{abstract}

Keywords: Proteocephalidea, Ophiotaenia gallardi, Vandiermenia beveridgei, Australotaenia grobeli, new species, morphology, Ophidia, Pseudechis porphyriacus

Between 2001 and 2003, the Department of Invertebrates of the Natural History Museum in Geneva, in collaboration with the South Australian Museum, Adelaide, the Queensland Museum, Brisbane and the University of Melbourne, Werribee, carried out a survey of the parasite fauna in Australia, with a focus on cestodes of reptiles and amphibians. As a part of evaluation of the material recently found or deposited in museum collections, the systematic status of Ophiotaenia gallardi (Johnston, 1911) (syn. Proteocephalus gallardi Johnston, 1911) and Ophiotaenia hylae Johnston, 1912 was assessed. A study of the type material of $O$. gallardi has shown that it contains a mixture of two taxa, one of them representing a new species belonging to a new genus.

\section{MATERIALS AND METHODS}

Freshly collected worms were fixed immediately after host dissection with a hot $4 \%$ neutral formaldehyde solution, sorted in laboratory and then, after 3 weeks, transferred to $75 \%$ ethanol for storage. Tapeworms for morphological observations were stained with Mayer's hydrochloric carmine, dehydrated in an ethanol series, cleared with eugenol (clove oil) and mounted in Canada balsam. Pieces of the strobila were embedded in paraffin wax, cross-sectioned (thickness 12-15 $\mu \mathrm{m}$ ), stained with Weigert's haematoxylin and counterstained with $1 \%$ acidic eosin B (Scholz and Hanzelová 1998, de Chambrier 2001).

Scoleces for scanning electron microscopy (SEM) were processed as follows: worms were dehydrated in a graded ethanol series $(80,96$, twice $100 \%)$, then transferred to a graded amyl acetate series, critical point dried in $\mathrm{CO}_{2}$, sputter-coated with

Address for correspondence: A. de Chambrier, Natural History Museum, P.O. Box 6434, CH-1211 Geneva 6, Switzerland. Phone: ++41 224 186 319 ; Fax: ++41 224186 301; E-mail: alain.dechambrier@ville-ge.ch or nomimoscolex2@yahoo.fr 
gold and examined with a Zeiss 940A electron microscope. Eggs were studied in distilled water. Microthrix terminology follows that of Chervy (2009). All measurements are given in micrometres $(\mu \mathrm{m})$ unless otherwise stated. For comparison, the type materials of all species of Australian Ophiotaenia were studied and measured (see Table 1). Abbreviations used in descriptions are as follows: $\mathrm{x}=$ mean; $\mathrm{n}=$ number of measurements; $\mathrm{CV}=$ coefficient of variability; $\mathrm{OV}=$ percentage of the width of the ovary versus the width of the proglottis; $\mathrm{PC}=$ percent of the length of cirrus-sac to the width of the proglottis; $\mathrm{PP}=$ position of the genital pore (cirrus pore) as the $\%$ of the proglottis length. MTJ = data of Johnston (1911); TM = present authors' data on type material; MHNG INVE = Natural History Museum, Collection of Invertebrate, Geneva, Switzerland; QM = Queensland Museum, Brisbane, Australia; AHC (new acronym) or SAM $($ old acronym $)=$ South Australian Museum, Parasitological Collection, Adelaide, Australia; BMNH = The Natural History Museum, London, UK.

\section{RESULTS}

Ophiotaenia gallardi (Johnston, 1911) Freze, 1965

Figs. 1-12

Description (based on 7 specimens): Proteocephalidae, Proteocephalinae. Cestodes up to $375 \mathrm{~mm}$ long $(\mathrm{MTJ}=400 \mathrm{~mm})$, up to $1.70 \mathrm{~mm}$ wide $(\mathrm{MTJ}=1.70$ $\mathrm{mm})$. Strobila acraspedote, anapolytic. Immature and mature proglottides wider than long to longer than wide, pregravid and gravid proglottides longer than wide (up to $3.65 \mathrm{~mm}$ long and up to $1.70 \mathrm{~mm}$ wide; $\mathrm{MTJ}=4.3$ to $5.25 \mathrm{~mm}$ long by $1-1.2 \mathrm{~mm}$ wide). Scolex $990-1605$ $(\mathrm{x}=1190, \mathrm{n}=12, \mathrm{CV}=13 \%$; MTJ $=960)$ wide, 595-895 $(\mathrm{x}=705, \mathrm{n}=12)$ long, slightly wider than neck (Figs. 1, $2,5)$, with small ovoid apical organ 40-50 $(x=45, n=4)$ wide (MTJ reported the presence of "an apical muscleplug, with a very small terminal cavity") (Fig. 5). Suckers uniloculate, ovoid, large, 400-635 $(\mathrm{x}=530, \mathrm{n}=11)$ $(\mathrm{MTJ}=440)$ wide. Proliferation zone about $7 \mathrm{~mm}$ long and 415-705 wide. Internal longitudinal musculature represented by small bundles of isolated muscular fibres (Figs. 9-11) forming anastomoses. Subtegumental muscles weakly developed (Fig. 11). Ventral osmoregulatory canals situated between testes and vitelline follicles. Dorsal osmoregulatory canals overlap testicular fields and separate them longitudinally (Figs. 7, 8). Genital atrium present, genital pores alternating irregularly, usually equatorial or slightly pre-equatorial; $\mathrm{PP}=35-54 \%$ $(x=46 \%, n=31, C V=8 \%)$ (Figs. 7, 8). Genital ducts passing between osmoregulatory canals (Fig. 12).

Testes medullary, in two lateral fields, each field longitudinally separated by dorsal osmoregulatory canals (Figs. 7, 8), forming three groups (poral, preporal and postporal), in one or two layers, sometimes slightly overlapping cirrus-sac (Fig. 8), numbering 67-103 ( $\mathrm{x}=81$, $\mathrm{n}=16, \mathrm{CV}=13 \%$ ); aporal testes $31-55$ in number; preporal testes 13-26 in number; postporal testes 15-27 in number. Testes spherical to oval, $65-110(\mathrm{x}=85, \mathrm{n}=24)$ in diameter, reaching almost to anterior margin of proglot- tides, but not to posterior one (Figs. 7, 8); present also in gravid proglottides. Cirrus-sac elongate to pyriform, thin-walled, 275-495 ( $\mathrm{x}=345, \mathrm{n}=31)$ long and $110-200$ $(\mathrm{x}=155, \mathrm{n}=18)$ wide (Fig. 12$) ; \mathrm{PC} 25-40 \%(\mathrm{x}=31 \%$, $\mathrm{n}=31, \mathrm{CV}=11 \%$ ). Cirrus represents up to $58 \%$ of cirrussac length $(n=14)$. Vas deferens coiled, situated between proximal part of cirrus-sac and midline of proglottides, never crossing it (Figs. 7, 8).

Ovary medullary, bilobate, relatively compact $610-725$ $(\mathrm{x}=650, \mathrm{n}=32)$ wide, $\mathrm{OV}=61-72 \%(\mathrm{x}=67 \% ; \mathrm{n}=32$; $\mathrm{CV}=4 \%)$. Mehlis' glands 55-60 $(\mathrm{x}=58, \mathrm{n}=5)$ in diameter, representing $6-8 \%$ of proglottis width (Fig. 7). Vitelline follicles medullary, arranged in two lateral fields near margins of proglottides, more numerous posteriorly, most follicles dorsal to midline in cross-sections (Figs. 9, 10), aporal vitelline follicles occupying $87-89 \%(x=87 \%$, $\mathrm{n}=5$ ) of proglottis length, poral vitelline follicles occupying $79-89 \%(x=86 \%, n=5)$ of proglottis length, interrupted at level of cirrus-sac. Vitelline follicles and testes present in gravid proglottides. Vaginal canal slightly curved before reaching seminal receptacle. Copulatory part of vagina surrounded by vaginal sphincter and intensely stained cells (Fig. 12). Vagina anterior (in 30\% of cases) or posterior (in $70 \%$ of cases) $(n=21)$, ventral to cirrus-sac (Fig. 12).

Primordium of uterine stem medullary, present in immature proglottides. Formation of uterus of Type 1 (sensu de Chambrier et al. 2004): in immature proglottides, uterine stem straight, occupying almost the entire length of proglottis, never crossing posteriorly ovarian isthmus, formed by longitudinal thick band of intensely stained cells along midline of proglottides. Lumen of uterus appearing in first mature proglottides (Fig. 7); diverticula (lateral branches) formed before first eggs appear in uterine stem. In pregravid proglottides, eggs completely filling uterine stem and thin-walled diverticula. In gravid proglottides, diverticula occupying up to $63 \%(n=7)$ of proglottis width; 23-30 lateral diverticula on each side. Some terminal gravid proglottides inflated with eggs, with visible ventral large, usually spherical uterine pore-like structures (Figs. 3, 4). Eggs with hyaline outer envelope, $110-120(\mathrm{n}=2)$ in diameter. Three-layered embryophore (see Conn and Świderski 2008) with thick supplementary spherical layer between outer envelope and oncosphere: first layer 37-40 $(n=9)$ in diameter, second layer 32-37 in diameter, third layer $18-22(\mathrm{n}=9)$ in diameter; oncosphere spherical, $11-12$ in diameter $(n=13)$, with three pairs of hooks. Eggs increase in size during intrauterine development. External surface of embryophore bearing small outgrowths (Fig. 6).

Type host: Pseudechis porphyriacus (Shaw) (Serpentes, Elapidae) (vernacular name: red-bellied black snake).

Type locality: Gippsland, Victoria, Australia, 1910.

Collector: A.S. Le Souef.

Site of infection: Intestine.

Material studied: Lectotype QM G12/110, Gippsland, 


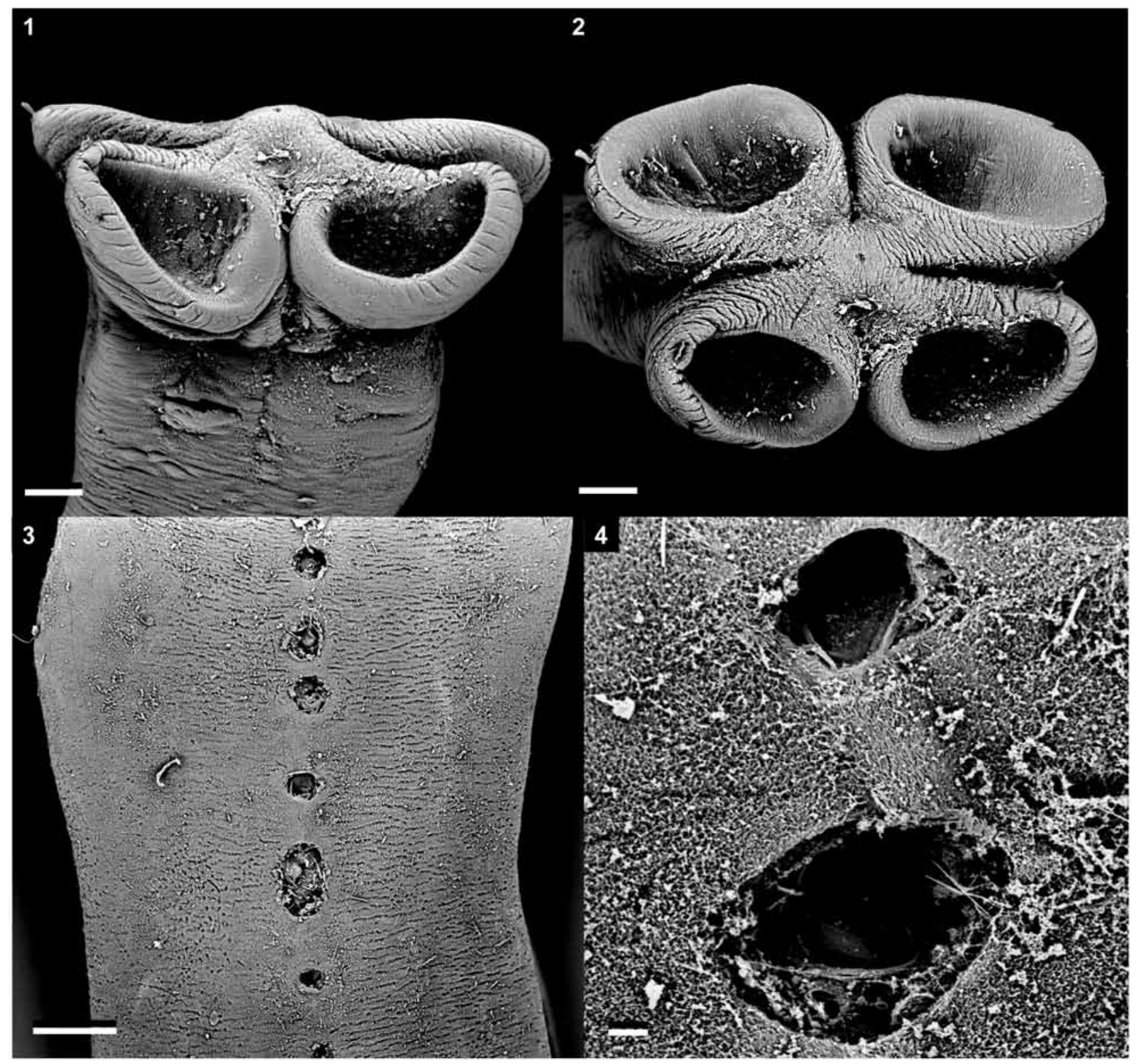

Figs. 1-4. Ophiotaenia gallardi (Johnston, 1911). Scanning electron micrographs. Fig. 1. Scolex, dorsoventral view (MHNG INVE 67494). Fig. 2. Scolex, apical view (MHNG INVE 67494). Fig. 3. Ventral view of a gravid proglottis, showing uterine pore-like structures (SAM 4375). Fig. 4. Detail of uterine pore-like structures (SAM 4375). Scale bars: Figs. 1, $2=100 \mu \mathrm{m} ;$ Fig. $3=200 \mu \mathrm{m}$; Fig. $4=20 \mu \mathrm{m}$.

Victoria, Australia, A.S. Le Souef 1910. Paralectotypes which are conspecific with the lectotype: QM G12/108-109, Narrara Near Gosford, NSW, Australia, L. Gallard 1910; AHC 20081 (= SAM 2295 in part), Victoria, collected by A.S. Le Souef. Other material: AHC 4374, 4375, 9890, 9892, 10731; MHNG INVE 67493 (field number Aus 011) Brisbane, QL, Australia; MHNG INVE 67494 (field number Aus 132), Taronga Park Zoo, NSW, Australia, 06.2003; BMNH 1968.5.28.16, Zoo. AHC 29989, 29990 (field number Aus 132), 1 specimen used for SEM.

Remarks. The original material of Proteocephalus gallardi (= Ophiotaenia gallardi) is in fact a mixture of two very distinct species belonging to different genera. In the original description (Johnston 1911), tapeworms illustrated in figures 1 and 2 of plate VII correspond to O. gallardi as described here whereas figure 3 represents a transverse section of another tapeworm, which is described below as a new species. In the original description, most measurements apparently refer to $O$. gallardi (Johnston, 1911).

From the nomenclatural point of view, we designate as lectotype for Ophiotaenia gallardi the "cotype" material from Gippsland, Victoria, Australia, collected by A.S. Le Souef, described and figured by Johnston (1911), numbered QM G12/110. The remaining syntypes are divided in "paralectotypes, which are conspecific with the lectotype" (i.e., these are the specimens of the type series used now in the redescription of this species) and "para- 

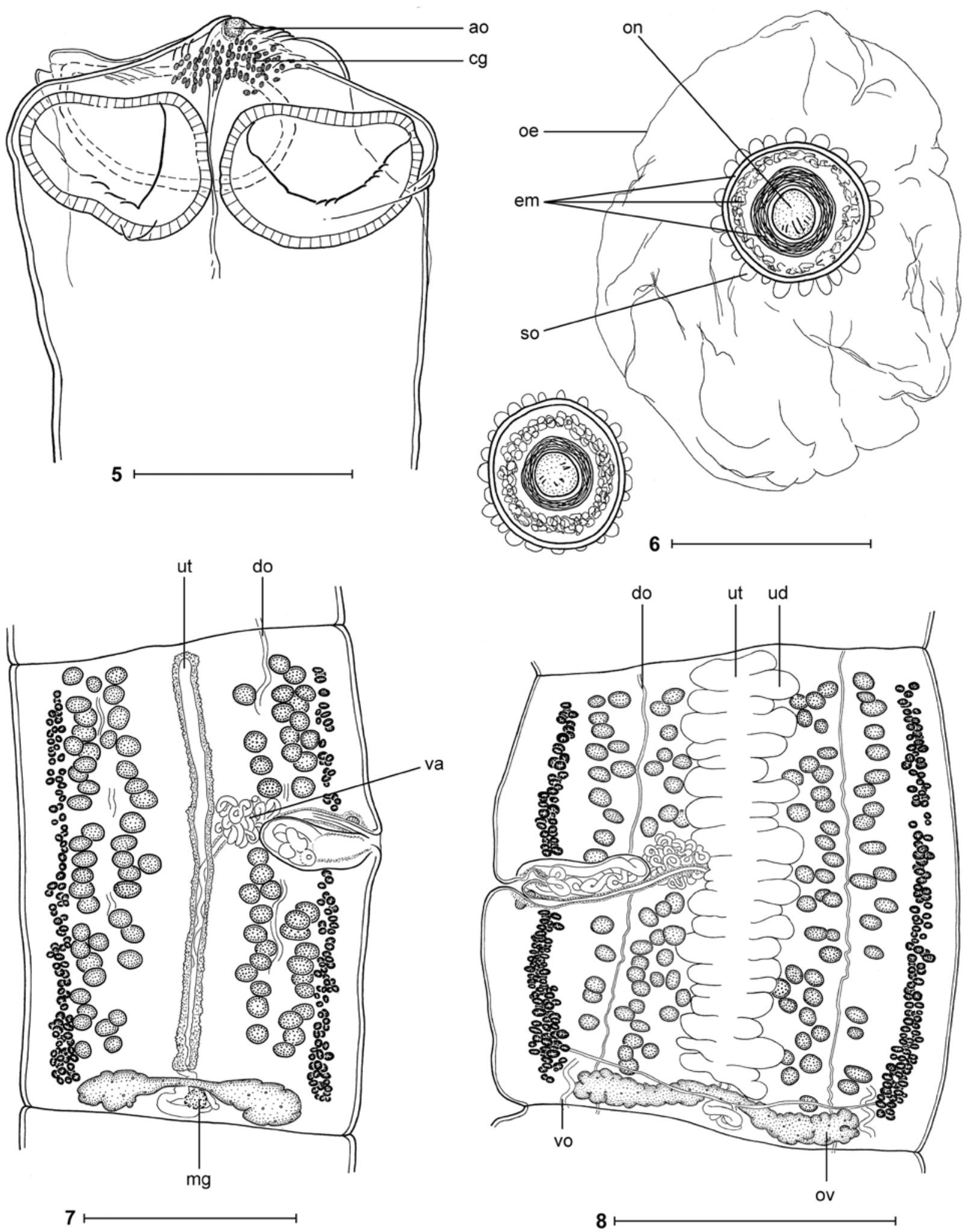

Figs. 5-8. Ophiotaenia gallardi (Johnston, 1911). Fig. 5. Syntype, scolex, ventral view (QM G12/110) (redrawn from Johnston 1911). Fig. 6. Eggs in distilled water, showing the three-layered embryophore and small outgrowths (SAM 4374). Fig. 7. Syntype, mature proglottis, dorsal view (QM G12/109) (redrawn from Johnston 1911) (ventral osmoregulatory canal not figured). Fig. 8. Pregravid proglottis, ventral view (SAM 4374 b); note the position of dorsal osmoregulatory canals, which separate longitudinally the testicular fields. Abbreviations: ao - apical organ; cg - cells with finely granular cytoplasm; do - dorsal osmoregulatory canal; em - three-layered embryophore; mg - Mehlis' glands; oe - outer envelope; on - oncosphere; ov - ovary: so - small outgrowths; ud - uterine diverticula; ut - uterus; va - vas deferens; vo - ventral osmoregulatory canal. Scale bars: Figs. 5, $7=500 \mu \mathrm{m}$; Fig. $6=50 \mu \mathrm{m}$; Fig. $8=1 \mathrm{~mm}$. 
lectotypes, which are not conspecific with the lectotype" (which are used for the description of Vandiermenia beveridgei). Note that the latter paralectotypes participate now in two type series: paralectotypes of $O$. gallardi and holotype and paratypes of Vandiermenia beveridgei described below.

Ninety-five species of Ophiotaenia parasitizing reptiles and amphibians are currently recognized as valid (Schmidt 1986, Ammann and de Chambrier 2008, Coquille and de Chambrier 2008, Marsella and de Chambrier 2008, de Chambrier et al. 2010); out of these, five have been found in Australia (Table 1). Ophiotaenia gallardi can be distinguished from these Australian species as follows: Ophiotaenia longmani Johnston, 1916 (considered as a species inquirenda by Freze 1965) and O. mjobergi (Nybelin, 1917) Wardle et McLeod, 1972 differ from O. gallardi by the total size of the body ( $94 \mathrm{~mm}$ in $O$. longmani and 150 $\mathrm{mm}$ in $O$. mjobergi versus $375 \mathrm{~mm}$ in $O$. gallardi), the number of testes (242-253 in O. longmani and 200-300 in $O$. mjobergi versus 67-103 in $O$. gallardi), the width of the scolex (650-800 in O. longmani and 750-800 in $O$. mjobergi versus 990-1605 in $O$. gallardi), the presence of clusters of eggs in O. longmani and O. mjobergi (eggs not clustered in $O$. gallardi), and the size of the embryophore (32-36 in O. longmani, 22-29 in O. mjobergi versus 37-40 in O. gallardi) (Table 1) (Freze 1965, Johnston 1916, Nybelin 1917, Wardle et McLeod 1952).

Ophiotaenia gallardi differs from the three remaining Australian Ophiotaenia species, all parasitic in lizards and amphibians (see Table 1), in the following characteristics: (i) the size of the cirrus-sac that represents $13-14 \%$ of the proglottis width in O. amphiboluri, $13-17 \%$ in O. striata and $17-19 \%$ in $O$. hylae versus $25-40 \%$ in O. gallardi; (ii) the number of uterine branches on each side numbering 15-20 in O. amphiboluri, 18-27 in O. striata and 10-17 in $O$. hylae versus 23-30 in O. gallardi; (iii) the size of the embryophore, which is 25 for $O$. amphiboluri, 27-30 for $O$. striata and 13-14 for O. hylae versus 37-40 for O. gallardi. Additionally, O. gallardi differs from O. striata and $O$. hylae by the diameter of the scolex (there is no scolex available for O. amphiboluri) (330-495 in O. striata and 340-390 in O. hylae versus 990-1605 in O. gallardi) and by the diameter of the testes (30 in O. striata, 35-60 in O. hylae versus 65-110 in O. gallardi). Furthermore, $O$. gallardi differs from $O$. amphiboluri by the presence of egg clusters in $O$. amphiboluri and from $O$. hylae by the type of uterine formation (Type 1 for $O$. gallardi and the three others species versus Type 2 for $O$. hylae).

Johnston (1912) found a cestode in a tiger snake Notechis scutatus (Peters) in the vicinities of Sydney and identified it as Proteocephalus gallardi. He also reported Proteocephalus sp., supposedly morphologically similar to $P$. gallardi, from two other venomous snakes, Pseudechis australis Gray and Denisonia superba Günther (=Austrelaps superbus). Johnston (1913) transferred
P. gallardi to Acanthotaenia and noted, after a careful comparison, that all four host species harbour the same species of cestode, Acanthotaenia gallardi. Meggitt (1927) placed this species in Crepidobothrium, whereas Freze (1965) transferred it to Ophiotaenia. The present authors concur with the proposal of Freze (1965). Tapeworms from Notechis scutatus identified as O. gallardi were sequenced by Zehnder and Mariaux (1999) and de Chambrier et al. (2004); they represent in fact a species new for science, the description of which is in progress. It also seems that cestodes from $P$. australis and $D$. $s u$ perba, which were considered by Johnston (1913) to be conspecific to $A$. gallardi, represent different species new for science (unpubl. data).

The presence of a three-layered embryophore, similar to that of $O$. gallardi described above, has already been observed in several proteocephalideans such as Kapsulotaenia sandgroundi (Carter, 1943), parasite of Varanus komodoensis and six other species from reptiles in the Australian region (de Chambrier 2006). The third, supplementary layer has also been recently described from proteocephalideans parasitic in lizards and amphibians in South America: Cairaella henrii Coquille et de Chambrier, 2008, a parasite of Norops trachyderma (Squamata), and Ophiotaenia alessandrae Marsella et de Chambrier, 2008 from Hyla boans (Anura) (Coquille and de Chambrier 2008, Marsella and de Chambrier 2008). Small outgrowths on the external surface of the embryophore have previously been observed in some proteocephalidean cestodes such as Vaucheriella bicheti de Chambrier, 1987 from a tropidophid snake in Ecuador, Nomimoscolex touzeti de Chambrier et Vaucher, 1992 from a Neotropical frog in Ecuador, Proteocephalus azevedoi de Chambrier, Vaucher et Renaud, 1992 from a Neotropical venomous snake in Brazil, Thaumasioscolex didelphidis CañedaGuzmán, de Chambrier et Scholz, 2001 from a Mexican marsupial, and Cairaella henrii (de Chambrier 1987, de Chambrier and Vaucher 1992, de Chambrier et al. 1992, Cañeda-Guzmán et al. 2001, Coquille and de Chambrier 2008).

In the Proteocephalidea, the wall of dorsal osmoregulatory canals is thicker than that of the ventral ones. Osmoregulatory canals that overlap and separate longitudinally testicular field are not common in Ophiotaenia. Only 4 out of 27 Ophiotaenia species parasitic in snakes of the New World harbour this character (see Coquille and de Chambrier 2008) which represents a good discriminative feature, as already pointed out for Nomimoscolex Woodland, 1934 by de Chambrier et al. (2006) and Ophiotaenia nicoleae Coquille et de Chambrier, 2008 (Coquille and de Chambrier 2008).

The type material of $O$. gallardi also included another species, which is described herein as new and for which a new genus is proposed. 
$9 \longmapsto$
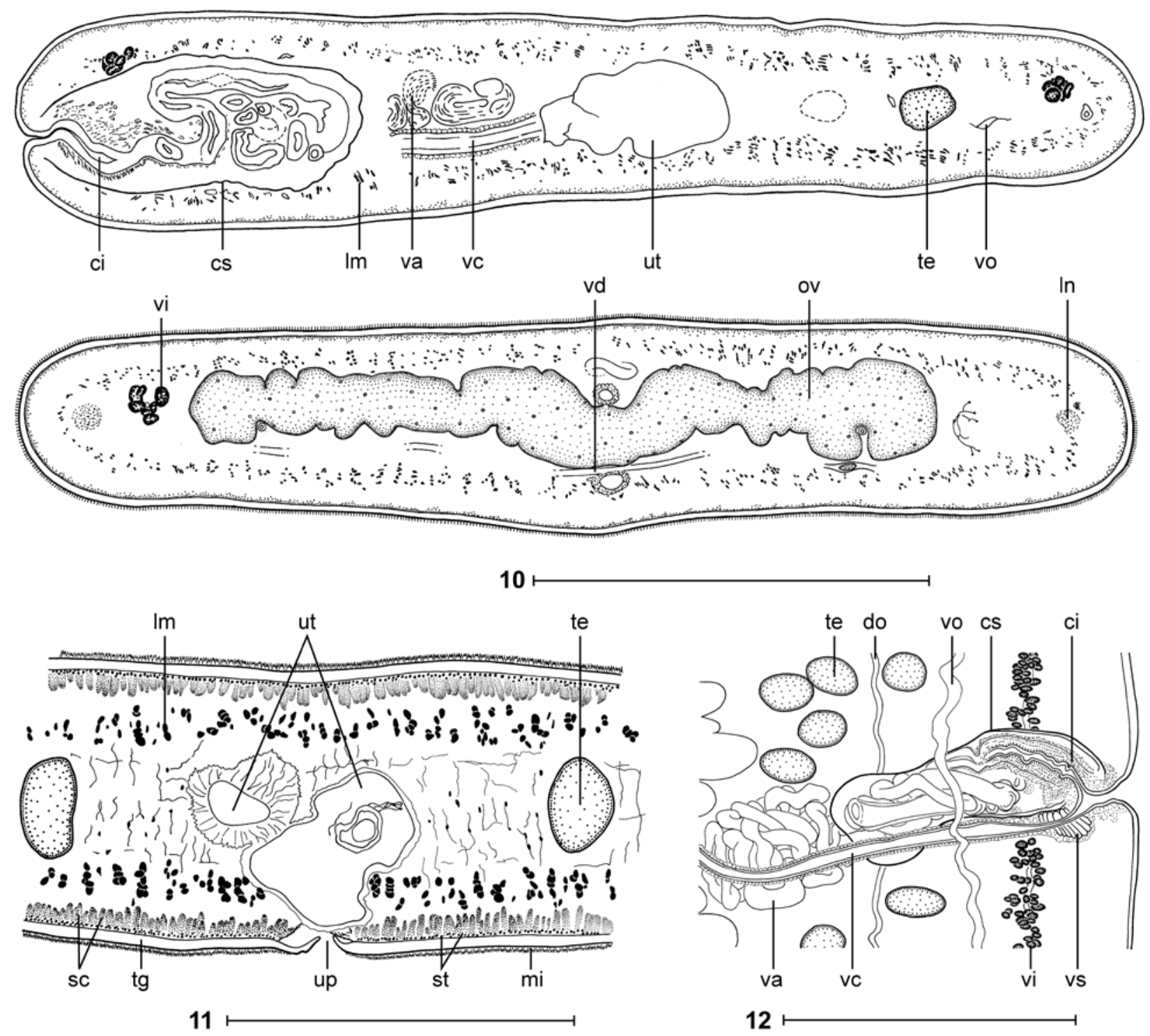

Figs. 9-12. Ophiotaenia gallardi (Johnston, 1911). Figs. 9, 10. Syntype (SAM 4374-16, 9). Cross-sections at the level of the cirrussac and ovary, respectively. Fig. 11. Cross-section at the level of the anterior part of pregravid proglottis (SAM 4375). Fig. 12. Vagina and cirrus-sac region, ventral view (SAM 4374c). Abbreviations: ci - cirrus; cs - cirrus-sac; do - dorsal osmoregulatory canal; $\mathrm{lm}$ - internal longitudinal musculature; ln - longitudinal nerve; mi - microtriches; ov - ovary; sc - subtegumental cells; st - subtegumental muscle fibres; te - testes; tg - tegument; up - uterine pore-like; ut - uterus; va - vas deferens; vc - vaginal canal; vd - vitelloduct; vi - vitelline follicles; vo - ventral osmoregulatory canal; vs - vaginal sphincter. Scale bars: Figs. 9, 10, $12=500 \mu \mathrm{m}$; Fig. $11=250 \mu \mathrm{m}$.

\section{Vandiermenia gen. $\mathrm{n}$.}

Diagnosis: Proteocephalidea, Proteocephalidae, Acanthotaeniinae. Small-sized worms, strobila acraspedote. Scolex with retractile rostellum-like organ, densely covered with capilliform filitriches and gladiate and aristate spinitriches, apex of pyramidal shape and with apical organ with musculo-glandular cells. Suckers uniloculate. Internal longitudinal musculature well developed. Secondary muscles fibres well developed. Testes medullary, in one field, in two layers. Vitelline follicles paramuscu- lar, in two lateral bands. Cirrus-sac small-sized, cupping glass-shaped. Vagina posterior or anterior to cirrus-sac. Genital pore posterior. Vas deferens strongly coiled. Mehlis' glands small. Ovary medullary, bilobed. Uterine stem cortical, growing from cortical stem into medulla. Uterine development of Type 1 sensu de Chambrier et al. (2004). Eggs in clusters. Parasites of snakes from the Australian Region. Type and only species: $V$. beveridgei $\mathrm{sp}$. n.

Etymology: The genus is named in honour of Mr. Martin van Diermen (Geneva). 
Differential diagnosis: The present genus is placed in the subfamily Acanthotaeniinae Freze, 1963. It fits the diagnosis given by Freze (1965) in having the massive anterior rostellum-like structure, muscular scolex bearing four highly mobile uniloculate suckers, surface of scolex covered with a dense network of capilliform filitriches and gladiate and aristate spinitriches, and medullary position of the ovary and testes. Vandiermenia differs from the other genera of the Acanthotaeniinae (Rostellotaenia Freze, 1963, Acanthotaenia von Linstow, 1903 and Kapsulotaenia Freze, 1963) by: (i) a well-developed internal longitudinal musculature in Vandiermenia versus weakly developed in the other acanthotaeniines, (ii) internal longitudinal musculature interrupted laterally versus uninterrupted in the other acanthotaeniines, (iii) testes in one field versus in two fields, (iv) cortical position of uterine stem versus medullar position, and (v) paramuscular position of vitellaria.

Furthermore, Vandiermenia differs from Acanthotaenia by the presence of clusters of eggs grouped in capsules, which are missing in the latter genus (Freze 1965). In Vandiermenia, the position of vagina relative to the cirrus-sac is anterior or posterior. It is always posterior in Kapsulotaenia (Freze 1965, de Chambrier 2006).

\section{Vandiermenia beveridgei $\mathrm{sp} . \mathrm{n}$.}

Figs. 13-34

Description (based on 7 specimens): Proteocephalidae, Acanthotaeniinae. Cestodes 55-62 mm long, 1400 wide. Strobila acraspedote, anapolytic. Immature and mature proglottides wider than long to longer than wide, pregravid and gravid proglottides longer than wide. Scolex 455-605 ( $\mathrm{x}=550, \mathrm{n}=7)$ long, 605-790 ( $\mathrm{x}=720$, $\mathrm{n}=7, \mathrm{CV}=8 \%$ ) wide, with spherical retractile rostellumlike organ $250-325(\mathrm{x}=300, \mathrm{n}=7)$ wide, and apical organ $140-170(x=160, n=7)$ wide. Apex of pyramidal shape. Retractor muscles seem not to be attached to the apical organ but to circular musculature posterior to apical organ (Figs. 33, 34). Proliferation zone narrower than scolex, 405-545 wide. Suckers antero-lateral, uniloculate, spherical, 210-325 $(\mathrm{x}=250, \mathrm{n}=21)$ in diameter. Sucker diameter represents $35 \%$ of scolex width (Figs. 13-15). Well-developed muscular band posterior to apical organ. Scolex covered with capilliform filitriches on apex, capilliform filitriches and gladiate spinitriches on rostellum-like organ and surface of suckers, and aristate spinitriches on surface of proliferation zone and strobila (Figs. 16-24). Internal longitudinal musculature well developed, composed of separated wide bundles of muscular fibres forming anastomoses, interrupted laterally on both sides (Figs. 27, 28). Secondary muscle fibres well developed, occupying almost entire cortical parenchyma (Figs. 27, 28). Osmoregulatory canals situated between testes and vitelline follicles (Figs. 25, 26). Ventral canals slightly wider than dorsal ones. Genital atrium present; genital pores alternating irregularly, always postequato- rial; $\mathrm{PP}=59-80 \%(\mathrm{x}=65 \%, \mathrm{n}=13, \mathrm{CV}=8 \%)$. Genital ducts passing between osmoregulatory canals (Figs. 25, 26).

Testes medullary in two layers, forming one field, not overlapping cirrus-sac, vagina and vas deferens (Figs. 25, 26), numbering 82-101 ( $\mathrm{x}=88, \mathrm{n}=9, \mathrm{CV}=6 \%)$; aporal testes $41-53$ in number; preporal testes $26-34$; postporal testes $8-15$. Testes spherical to oval, 40-80 long, 25-55 $(\mathrm{n}=11)$ wide, not reaching vitelline follicles laterally (Figs. 25, 26), disappearing in last gravid proglottides. Cirrus-sac pyriform, thick-walled in its distal part, 179$210(\mathrm{x}=190, \mathrm{n}=13, \mathrm{CV}=6 \%)$ long by $85-105(\mathrm{x}=95$, $\mathrm{n}=13, \mathrm{CV}=5 \%$ ) wide (Figs. 26, 27, 31, 32); PC 20$31 \%(\mathrm{x}=24 \%, \mathrm{n}=13, \mathrm{CV}=15 \%)$. Posterior part of cirrus slightly coiled (Fig. 30). Vas deferens strongly coiled, occupying a very large area, situated between proximal part of cirrus-sac and crossing midline of proglottides (Fig. 25).

Ovary medullary, bilobed, 295-545 $(\mathrm{x}=410, \mathrm{n}=13)$ wide, $\mathrm{OV}=48-59 \%(\mathrm{x}=53 \%, \mathrm{n}=13, \mathrm{CV}=6 \%)$ (Figs. $19,21)$. Mehlis' glands 45-65 $(\mathrm{x}=57, \mathrm{n}=9, \mathrm{CV}=12 \%)$ in diameter, representing $6-10 \%$ of proglottis width (Figs. 25, 26). Vitelline follicles paramuscular, arranged in two lateral fields near margins of proglottides, slightly more numerous posteriorly, occupying $84-96 \%(x=89 \%$, $\mathrm{n}=15, \mathrm{CV}=4 \%$ ) of proglottis length, interrupted at level of cirrus-sac and vagina (Figs. 25, 26). Vagina anterior $(40 \%)$ or posterior $(60 \%)(n=40)$ to cirrus-sac. Copulatory part of vagina surrounded by glandular cells but no vaginal sphincter present (Figs. 30, 31). Seminal receptacle antero-dorsal to ovarian isthmus.

Primordium of uterine stem cortical, present in immature proglottides. Formation of uterus of Type 1 (sensu de Chambrier et al. 2004): in immature proglottides, uterine stem straight, formed by longitudinal wide column of intensely stained cells along midline of proglottides, not reaching anterior margin of proglottis and not crossing over ovarian isthmus (Fig. 26); lumen of uterus appearing in first mature proglottides. Uterine diverticula (lateral branches) formed before first eggs appear in uterine stem and growing from cortical stem into medullary region. In pregravid proglottides, eggs completely filling uterine stem and thick-walled diverticula. In gravid proglottides, diverticula occupying up to $76 \%$ of proglottis width; $22-$ 26 lateral branches on each side (Fig. 26) with some outgrowths penetrating dorsal cortex. Ventral uterine opening not observed. Eggs in clusters of three $(76 \%)$, less frequently of four $(16 \%)$, two $(6 \%)$ or five $(1 \%), n=77$. Clusters clover-shaped, thick-walled, with hyaline outer envelopes, 85-95 in diameter (Fig. 32). Embryophore in three layers, external one surrounding 2 to 5 eggs, 62-70 in diameter; spherical second layer 27-30 in diameter; spherical dense third layer 18-23 in diameter; oncosphere spherical, 11-12 in diameter, with three pairs of hooks, 4-5 long (Fig. 33). 

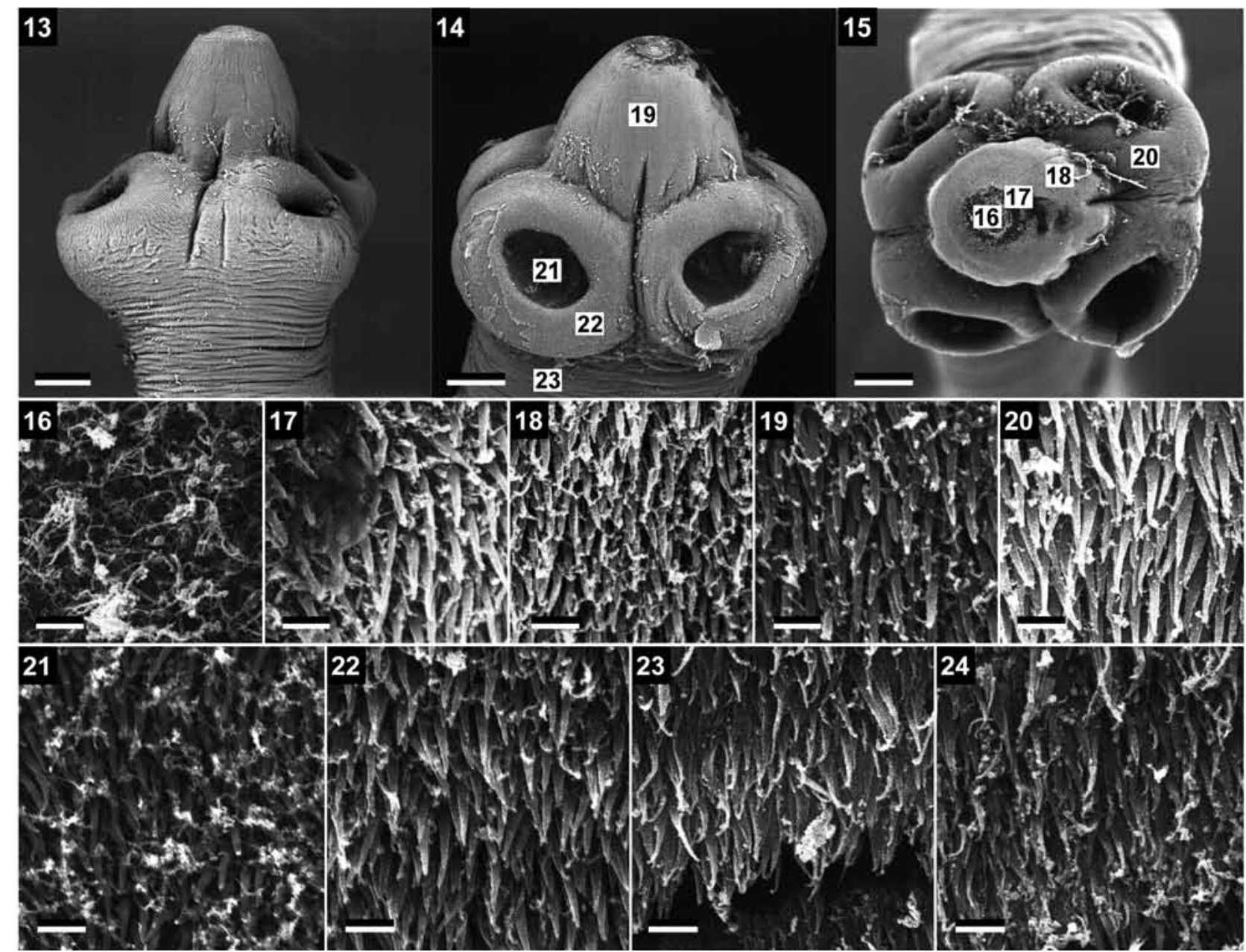

Figs. 13-24. Vandiermenia beveridgei gen. et sp. n. Paratypes (SAM 32339). Scanning electron micrographs. Fig. 13. Scolex, lateral view. Fig. 14. Scolex, dorsoventral view. Note: small numbers correspond to the figures showing higher magnification images of these surfaces. Fig. 15. Scolex, apical view. Fig. 16. Capilliform filitriches on the centre of the apical organ. Fig. 17. Capilliform filitriches and gladiate spinitriches on the margin of the apical organ. Fig. 18. Capilliform filitriches and gladiate spinitriches on the upper part of the surface of pyramidal apex. Fig. 19. Gladiate spinitriches on the middle part of the pyramidal apex surface. Fig. 20. Gladiate spinitriches on the external upper surface of suckers. Fig. 21. Capilliform filitriches and gladiate spinitriches on the internal surface of suckers. Fig. 22. Capilliform filitriches and gladiate spinitriches on the marginal surface of sucker. Fig. 23. Aristate spinitriches on the surface of the proliferation zone. Fig. 24. Aristate spinitriches on the surface of mature proglottis. Scale bars: Figs. $13-15=100 \mu \mathrm{m}$; Figs. $16-24=2 \mu \mathrm{m}$.

Type host: Pseudechis porphyriacus (Shaw) (Serpentes, Elapidae) (vernacular name: red-bellied black snake).

Type locality: Narrara, Gosford District, NSW, Australia. Site of infection: Intestine.

Type material: Holotype AHC 20080 (= SAM 2293), Narrara, Gosford District, NSW, Australia, 1910, collected by L. Gallard (= paralectotype of which are not conspecific with the lectotype of $O$. gallardi, see above). Paratype SAM 32339, Western Plain Zoo, Dubbo, NSW, 8.6.1999; paratype AHC 3778, Adelaide Zoo, "from Queensland"; paratype AHC 28405, Richmond, NSW, 1909. Other material in alcohol: paratype AHC 3778, Adelaide Zoo, "from Queensland".

Etymology: The species is named in honour of Prof. Ian Beveridge (University of Melbourne, Werribee, Victoria, Australia) for his contribution to the systematics of cestodes.
Remarks. In addition to the presence of a powerful internal longitudinal musculature, unique within the Acanthotaeniinae, we noted the presence of secondary longitudinal muscle fibres situated in the cortex. Within the Proteocephalidea, these characters are very rare. Woodland (1934a, p. 147) pointed out this particular muscle system in Myzophorus admonticellia Woodland, 1934 (= Nomimoscolex admonticellia) and used this character to place the species within the Phyllobothriidae (currently a family of the Tetraphyllidea; see Euzet 1994). We also found these two characters in Myzophorus dorad Woodland, 1935 (= Nomimoscolex dorad), parasite of Brachyplatystoma rousseauxi (Pimelodidae), and also in Nomimoscolex suspectus Zehnder, de Chambrier, Vaucher et Mariaux, 2000 and Endorchis piraeeba Woodland, 1934, 


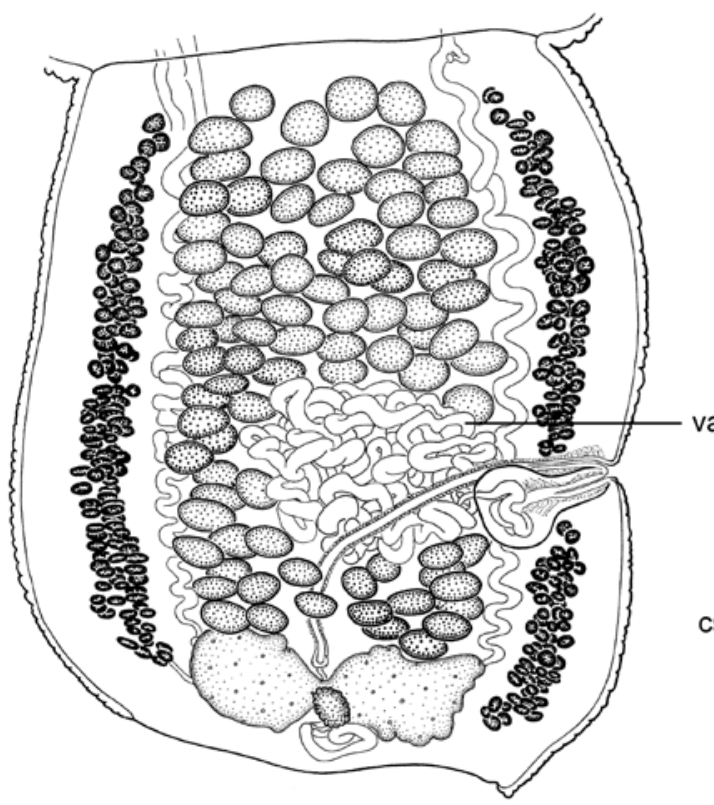

25

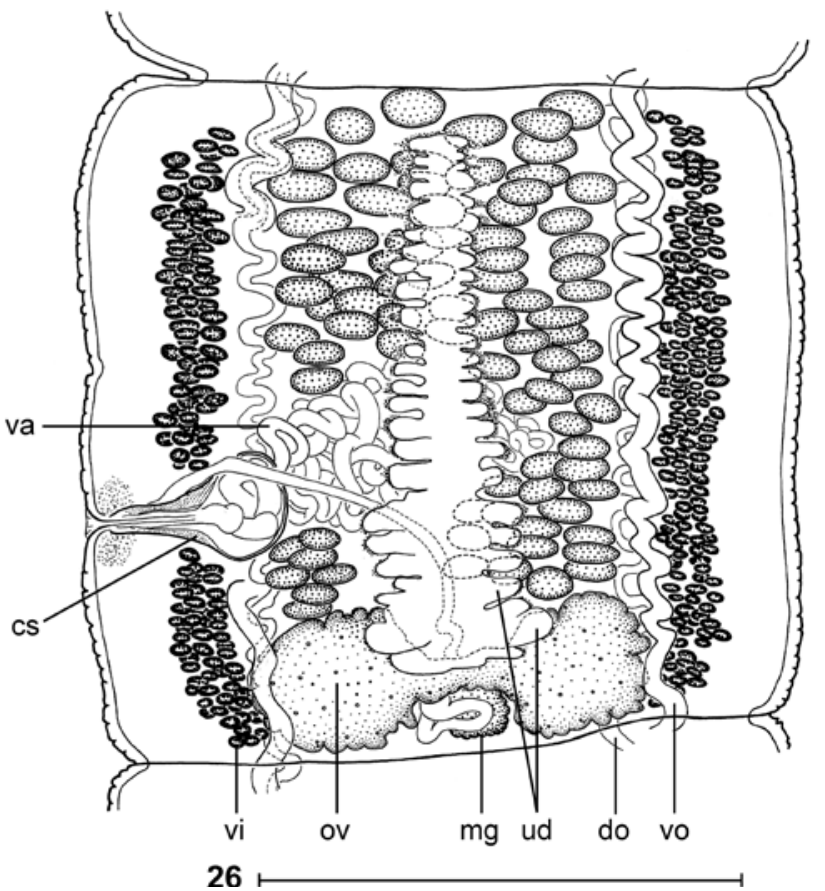

26

Figs. 25, 26. Vandiermenia beveridgei gen. et sp. n. Paratypes (SAM 32339). Fig. 25. Mature proglottis in dorsal view, uterine stem not figured. Fig. 26. Pregravid proglottis in ventral view. Abbreviations: cs - cirrus-sac; do - dorsal osmoregulatory canal; mg - Mehlis' glands; ov - ovary; ud - uterine diverticula; va - vas deferens; vi - vitelline follicles; vo - ventral osmoregulatory canal. Scale bars $=500 \mu \mathrm{m}$.

both parasites of Brachyplatystoma filamentosum (Pimelodidae) (Woodland 1934a,b, 1935a, de Chambrier and Vaucher 1997, Zehnder et al. 2000). All these also possess a cortical uterine stem with the medullary development of uterine diverticula, similarly as it is in $V$. beveridgei.

Another peculiar character of $V$. beveridgei is the absence of internal longitudinal muscles on lateral sides of body (Figs. 28, 29): to our knowledge, only Postgangesia orientalis Akhmerov, 1969 (see figure 17 in de Chambrier et al. 2003), Houssayela sudobim Woodland, 1935 (see figures 19, 20 in Woodland 1935a and figures 4, 5, 12 in de Chambrier et Scholz 2005) and Ophiotaenia hylae possess this character.

Based on available data (museum material, field numbers of hosts), it seems that $O$. gallardi and $V$. beveridgei do not occur simultaneously in their host, Pseudechis porphyriacus.

\section{Australotaenia gen. n.}

Diagnosis: Proteocephalidea, Proteocephalidae, Acanthotaeniinae. Medium-sized worms, strobila acraspedote. Scolex with a retractile glandulo-muscular rostellum-like organ. Suckers uniloculate. Internal longitudinal musculature well developed, in form of few large bundles of fibres. Testes medullary, in one field, in two layers. Vitelline follicles cortical, in two lateral bands. Vagina posterior or anterior to cirrus-sac. Mehlis' glands small. Ovary medullary, bilobed. Uterine stem cortical, growing from cortical stem into medullary region. Uterine development of Type 2 sensu de Chambrier et al. (2004). Parasites of amphibians from the Australian Region. Type species: Australotaenia hylae (Johnston, 1912) comb. n.; synonyms: Ophiotaenia hylae Johnston, 1912; Batrachotaenia hylae (Johnston, 1912) Rudin, 1917; Batrachotaenia hylae (Johnston, 1912) Freze, 1965.

Etymology: The genus has been named in reference to its geographical range; name should be treated as being of feminine gender.

Remarks. The comparison of $O$. gallardi with congeneric species from Australian reptiles and amphibians has shown that $O$. hylae, a parasite of Litoria aurea, possesses a very peculiar scolex with a glandulo-muscular rostellum-like organ. A new genus is proposed to accommodate this species and it is placed in the subfamily Acanthotaeniinae.

The new genus Australotaenia differs from all but one (Vandiermenia) of the subfamily Acanthotaeniinae by (i) the Type 2 of uterine formation (sensu de Chambrier et al. 2004), (ii) the morphology of the scolex, which is without muscle band, (iii) the cortical position of the uterine stem, (iv) the morphology of the internal longitudinal musculature in form of few large bundles of fibres and (v) the absence of internal longitudinal musculature on the lateral side of the body (Figs. 53, 54). Australotaenia differs from Vandiermenia by the type of uterine development (see de Chambrier et al. 2004) (Type 2 versus Type 1 

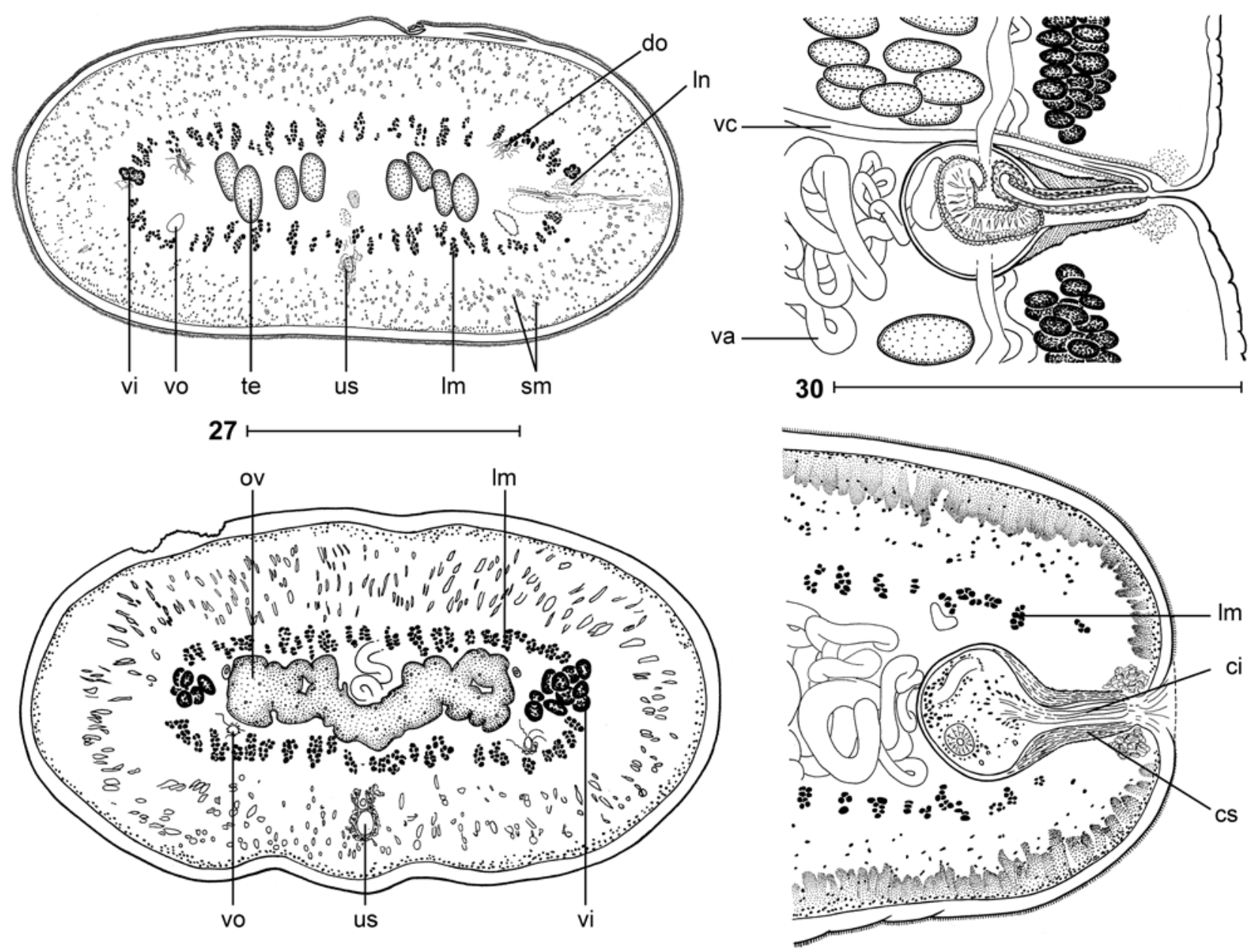

28 $-1$

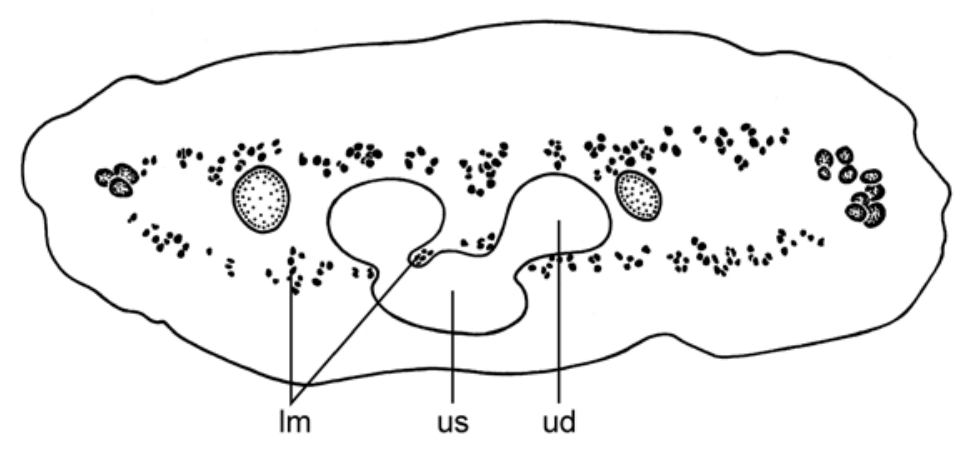

29

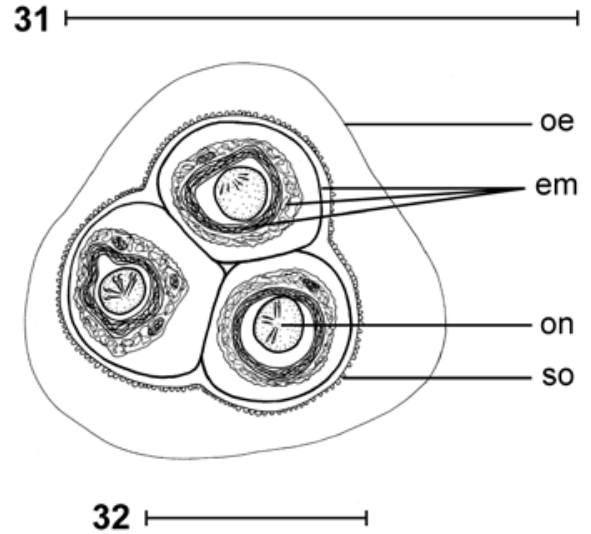

Figs. 27-32. Vandiermenia beveridgei gen. et sp. n. Fig. 27. Holotype (SAM 20080), cross-section at the level of the cirrus-sac (redrawn from Johnston 1911). Fig. 28. Paratype (SAM 3778-5), cross-section at the level of the ovary. Fig. 29. Paratype (SAM 3778), cross-section at the anterior part of a pregravid proglottis. Fig. 30. Paratype (SAM 32339), vagina and cirrus-sac region, ventral view. Fig. 31. Paratype (SAM 32339), cross-section at level of the cirrus-sac. Fig. 32. Eggs drawn in distilled water, showing the three-layered embryophore and external small outgrowths. Abbreviations: ci - cirrus; cs - cirrus-sac; do - dorsal osmoregulatory canal; em - three-layered embryophore; $1 \mathrm{~m}$ - internal longitudinal musculature; $1 \mathrm{n}$ - longitudinal nerve; oe - outer envelope; on - oncosphere; ov - ovary; sm - secondary musculature; so - small outgrowths; te - testes; ud - uterine diverticula; us - uterine stem; va - vas deferens; vc - vaginal canal; vi - vitelline follicles; vo - ventral osmoregulatory canal. Scale bars: Figs. 27-29=500 $\mu \mathrm{m}$; Figs. $30,31=250 \mu \mathrm{m}$; Fig. $32=20 \mu \mathrm{m}$. 

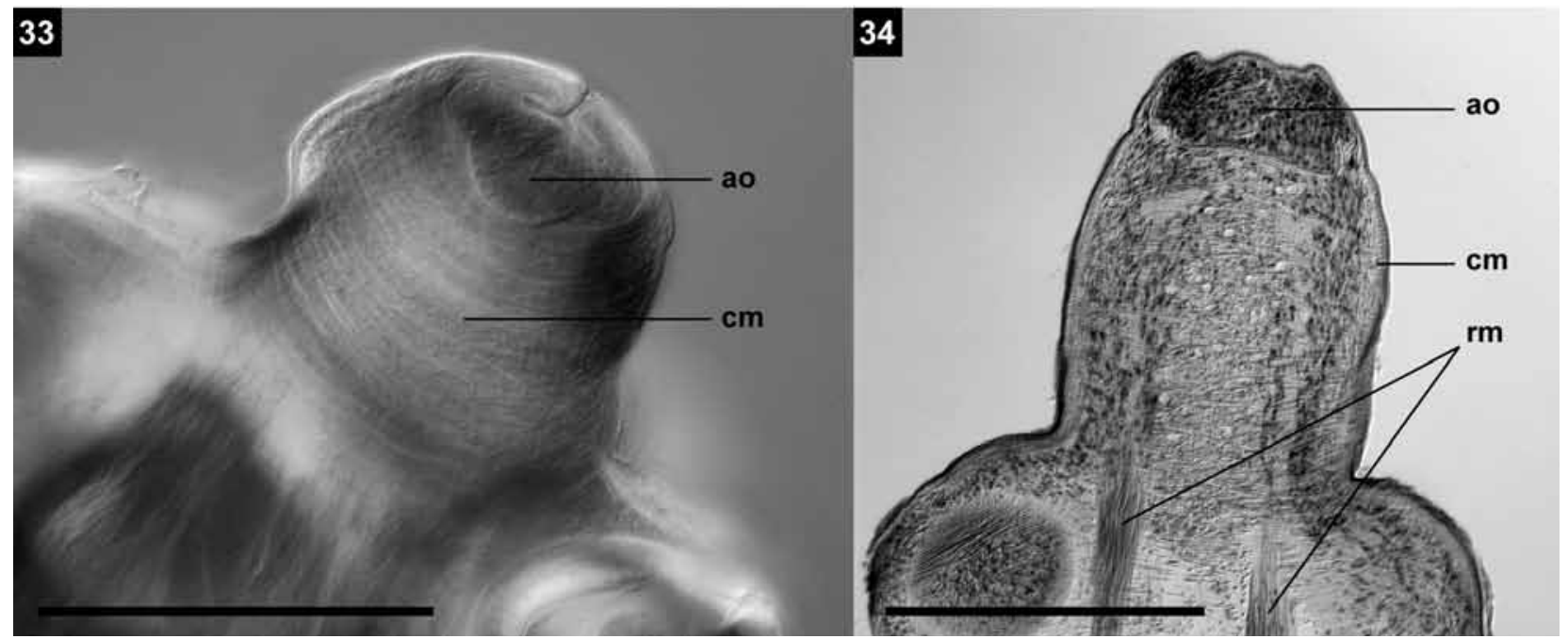

Figs. 33, 34. Vandiermenia beveridgei gen. et sp. n. Paratype (SAM 32339). Photomicrographs. Fig. 33. Pyramidal apex showing the apical part retracted. Fig. 34. Frontal section of the scolex, showing the apical organ and the retractor muscle. Abbreviations: ao - apical organ; $\mathrm{cm}$ - circular musculature; $\mathrm{rm}$ - retractor muscle. Scale bars $=100 \mu \mathrm{m}$.

in Vandiermenia), eggs not grouped in clusters (clustered in Vandiermenia), two testicular fields (versus one in Vandiermenia), the structure of the longitudinal internal musculature with 8-10 isolated bundles without secondary muscles versus well-developed muscles with numerous bundles and secondary muscles in Vandiermenia. Furthermore, the scolex of Australotaenia has not a muscular pyramidal apex, which is present in Vandiermenia.

The type species, A. hylae, was redescribed by de Chambrier (2004), on the basis of the type material. As noted by de Chambrier et al. (2004), the structure and development of the uterus has long been recognised as a major source of information for cestode systematics (Hoberg et al. 1999, Beveridge 2003). Within the Proteocephalidea, two distinct types of uterine development were recognised (de Chambrier et al. 2004). The Type 1 is typical of two basal groups, the Acanthotaeniinae and the Gangesiinae, but also of species of Ophiotaenia from viperid and elapid snakes. As argued by de Chambrier et al. (2004), the uterine development character appears to be the most adequate to define the higher-level lineages (or taxa?) of the Proteocephalidea. The presence of the Type 2 of uterine development in Australotaenia, which is unique among the Acanthotaeniinae, the species of which have the Type 1 of uterine development, is a strong argument for the erection of the new genus.

The retractor muscles linked to a rostellum-like apical structure was observed mainly in the Gangesiinae (Freze 1965, de Chambrier et al. 2003) but Freze (1965) did not mention such a retractor muscle for the Acanthotaeniinae. The rostellum-like organ, in the second species of Australotaenia described below, can be evaginated (Figs. 39, 40) or invaginated (Figs. 43, 44).
The muscular band posterior to the apical organ is markedly large in Vandiermenia beveridgei (Fig. 33), large in Kapsulotaenia sandgroundi (see de Chambrier 2006) and narrow in Australotaenia hylae (Fig. 35) as well as in the second species of Australotaenia (Fig. 50).

The cortical position of the uterine stem, which develops diverticula in the medulla, was reported for Nomimoscolex piraeeba Woodland, 1934 by Woodland (1934a) but this character was misinterpreted: “... the uterus lies almost entirely in the medulla, but mid-ventrally small portions project into the cortex". De Chambrier and Vaucher (1997) observed in this species that the uterine stem is in the ventral cortex and develops diverticula within the medulla as it is also the case in Endorchis piraeeba Woodland, 1934, another species parasitic in pimelodid catfishes in South America. This feature was also observed in Harriscolex kaparari (Woodland, 1935), Endorchis auchenipteri de Chambrier et Vaucher, 1999, Gibsoniela meursaulti de Chambrier et Vaucher, 1999, Nomimoscolex chubbi (Pavanelli et Takemoto, 1995) and N. suspectus Zehnder, de Chambrier, Vaucher et Mariaux, 2000, (Woodland 1934a, 1935b, Pavanelli and Takemoto 1995, Chambrier and Vaucher 1997, 1999, Zehnder et al. 2000).

One of the diagnostic characters of the Acanthotaeniinae is the weak internal longitudinal musculature (Freze 1965 , p. 423). However, the internal longitudinal musculature of Australotaenia is composed of 4-5 large isolated bundles of fibres situated dorsally and ventrally (Figs. 52-54). In Vandiermenia, the internal longitudinal musculature is also well developed (Figs. 27-29, 31). Despite this discrepancy, both genera are placed in this subfamily because they possess other characteristics of the Acantho- 

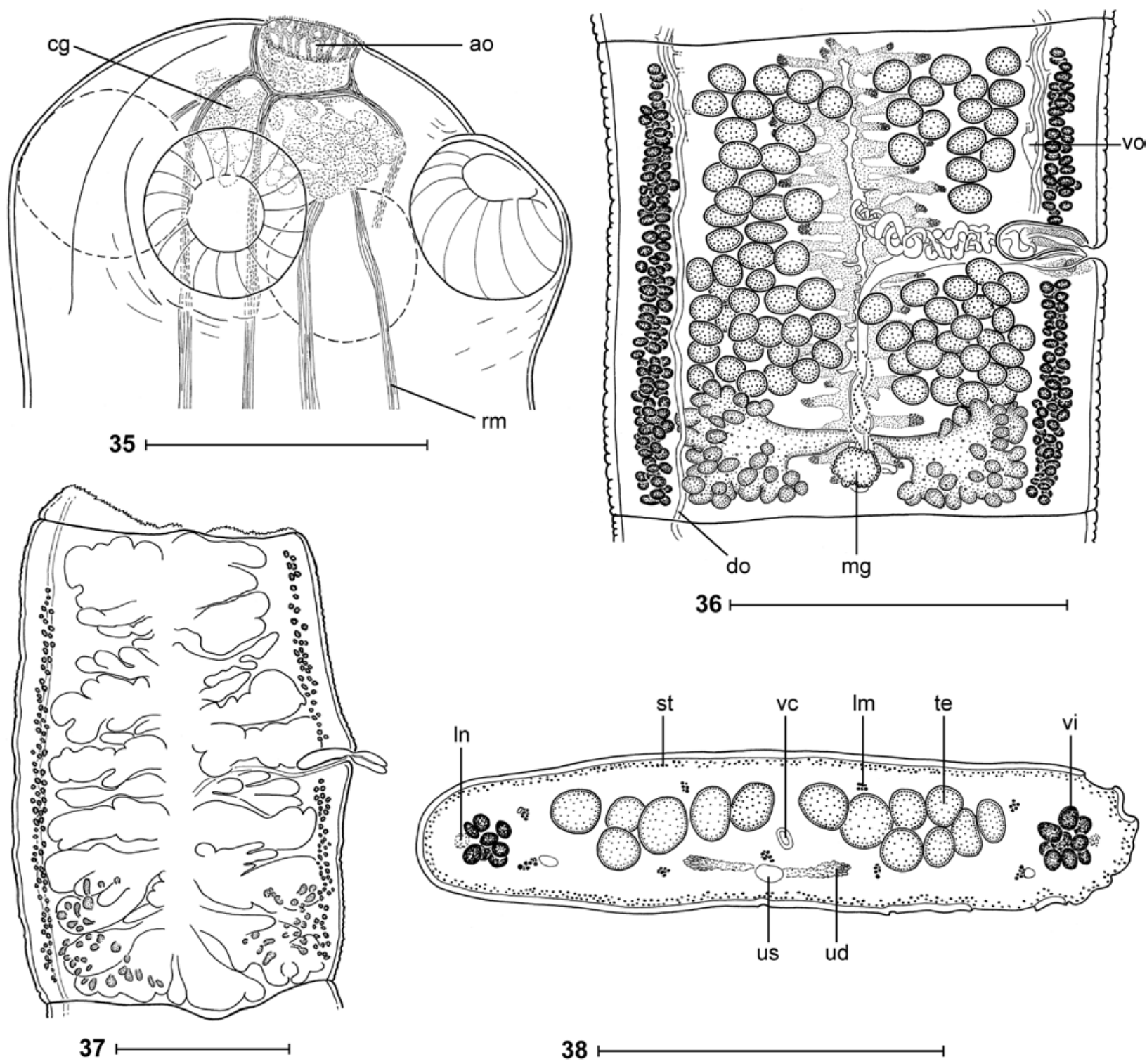

38

Figs. 35-38. Australotaenia hylae (Johnston, 1912). Fig. 35. Syntype (SAM 20689), scolex, dorsoventral view (from de Chambrier 2004, with permission of Revue Suisse de Zoologie). Fig. 36. Syntype (SAM 44141), mature proglottis, dorsal view (from de Chambrier 2004, modified). Fig. 37. Syntype (SAM 20689), gravid proglottis, dorsal view (from de Chambrier 2004). Fig. 38. Syntype SAM 2325, cross-section at the level of the posterior part of mature proglottis (original). Abbreviations: ao - apical organ; cg - cells with finely granular cytoplasm; do - dorsal osmoregulatory canal; lm - internal longitudinal musculature; ln - longitudinal nerve; mg - Mehlis' glands; rm - retractor muscle; st - subtegumental muscle fibres; te - testes; ud - uterine diverticula; us - uterine stem; vc - vaginal canal; vi - vitelline follicles; vo - ventral osmoregulatory canal. Scale bars: Fig. $35=200 \mu \mathrm{m}$; Figs. 36-38 $=500 \mu \mathrm{m}$.

taeniinae, in particular a holdfast apparatus is not present in any other proteocephalidean subfamily (Freze 1965, Rego 1994).

In almost all proteocephalidean cestodes, the internal layer of the longitudinal musculature forms an uninterrupted circle in cross-section, separating the cortex from the medulla. It is very rare to observe the internal layer of longitudinal musculature to be absent laterally. This characteristic has been reported for three species of un- related subfamilies (Gangesiinae and Zygobothriinae), namely Nomimoscolex dorad (Woodland, 1935), N. suspectus Zehnder, de Chambrier, Vaucher et Mariaux, 2000 and Postgangesia orientalis Akhmerov, 1969 (Woodland 1935, Zehnder et al. 2000, de Chambrier et al. 2003). This feature is also reported for Australotaenia hylae as well as for the new Australotaenia species described herein and Vandiermenia beveridgei. 
Table 1. Species of Ophiotaenia and Australotaenia parasitizing reptiles and amphibians in Australia. Measurements in $\mu \mathrm{m}$ unless otherwise stated.

\begin{tabular}{|c|c|c|c|c|c|c|c|}
\hline Species & $\begin{array}{l}\text { O. longmani } \\
\text { Johnston, } 1916 \\
\text { sp. inquirenda }\end{array}$ & $\begin{array}{l}\text { O. mjobergi } \\
\text { (Nybelin, 1917) }\end{array}$ & $\begin{array}{l}\text { O. amphiboluri } \\
\text { (Nybelin, 1917) } \\
\text { sp. inquirenda }\end{array}$ & $\begin{array}{l}\text { O. striata } \\
\text { (Johnston, 1914) } \\
\text { sensu lato }\end{array}$ & $\begin{array}{l}\text { O. gallardi } \\
\text { (Johnston, } \\
1911 \text { ) }\end{array}$ & $\begin{array}{l}\text { A. hylae } \\
\text { (Johnston, } \\
1912)^{1}\end{array}$ & A. grobeli $\mathrm{sp} . \mathrm{n}$. \\
\hline Source of data & Johnston 1916 & Nybelin 1917 & Nybelin 1917 & Johnston 1914 & Present study & $\begin{array}{l}\text { de Chambrier } \\
2004\end{array}$ & $\begin{array}{l}\text { de Chambrier } \\
2004\end{array}$ \\
\hline \multirow[t]{2}{*}{ Host } & $\begin{array}{l}\text { Aspidites } \\
\text { ramsayi }\end{array}$ & $\begin{array}{l}\text { Demansia } \\
\text { psammophis }\end{array}$ & $\begin{array}{l}\text { Pogona } \\
\text { barbata }\end{array}$ & $\begin{array}{l}\text { Lialis } \\
\text { burtoni }\end{array}$ & $\begin{array}{l}\text { Pseudechis } \\
\text { porphiriacus }\end{array}$ & $\begin{array}{l}\text { Litoria } \\
\text { aurea }\end{array}$ & $\begin{array}{l}\text { Litoria } \\
\text { moorei }\end{array}$ \\
\hline & Ophidia & Ophidia & Squamata & Squamata & Ophidia & Amphibia & Amphibia \\
\hline & & & & & & & \\
\hline Total length & 94 mm* & $150 \mathrm{~mm} *$ & not described & $33 \mathrm{~mm}$ or more* & $375 \mathrm{~mm}$ & $121 \mathrm{~mm}$ & $57-98 \mathrm{~mm}$ \\
\hline Proglottis width & $1 \mathrm{~mm} *$ & $2 \mathrm{~mm}^{*}$ & $1250-1650$ & $1-1.5 \mathrm{~mm} *$ & 1685 & $710-920$ & 755 \\
\hline Scolex width & $650-800 *(935)$ & $750-880$ & not described & $330-495$ & $990-1605$ & $340-390$ & $245-420$ \\
\hline Suckers width & $350-400 *(345-360)$ & $325-430$ & not described & $115-120$ & $400-635$ & $130-135$ & $100-140$ \\
\hline Apical organ & absent & absent & not described & not visible & $40-50$ & $65-80$ & $70-110$ \\
\hline Neck width & $700 *$ & $795-815$ & not described & 385 & $415-705$ & 365 & $200-360$ \\
\hline Testis number & $242-253$ & $200-300 *$ & $100-115^{*}$ & $72-79$ & $67-103$ & $74-106$ & $46-76$ \\
\hline Testis diameter & $30-50 \times 20-30 *$ & $75-80 \times 45-55^{*}$ & $90-125 \times 45-55$ & $30 *$ & $65-110$ & $35-60$ & $50-80$ \\
\hline $\mathrm{PC}$ & $32-36 \%$ & $25-28 \%$ & $13-14 \%$ & $13-17 \%$ & $25-40 \%$ & $17-19 \%$ & $27-33 \%$ \\
\hline PP & $50-53 \%$ & $39-51 \%$ & $62-73 \%$ & $48-51 \%$ & $35-54 \%$ & $44-55 \%$ & $46-57 \%$ \\
\hline $\mathrm{OV}$ & $58-67 \%$ & $53-64 \%$ & $68-73 \%$ & $63-74 \%$ & $61-72 \%$ & $68-71 \%$ & $55-63 \%$ \\
\hline Vagina & $\begin{array}{l}\text { anterior/ } \\
\text { posterior }\end{array}$ & $\begin{array}{l}\text { anterior/ } \\
\text { posterior }\end{array}$ & $\begin{array}{l}\text { anterior/ } \\
\text { posterior }\end{array}$ & anterior & $\begin{array}{l}\text { anterior/ } \\
\text { posterior }\end{array}$ & $\begin{array}{l}\text { anterior/ } \\
\text { posterior }\end{array}$ & $\begin{array}{l}\text { anterior/ } \\
\text { posterior }\end{array}$ \\
\hline Vaginal sphincter & present* & present* & present* & present & present & present & present \\
\hline Uterine branches & $\begin{array}{l}41-42 \text { on } \\
\text { each side }\end{array}$ & $\begin{array}{l}30-40 \text { on } \\
\text { each side* }\end{array}$ & $\begin{array}{l}15-20 \text { on } \\
\text { each side* }\end{array}$ & $\begin{array}{l}18-27 \text { on } \\
\text { each side }\end{array}$ & $\begin{array}{l}\text { 23-30on } \\
\text { each side }\end{array}$ & $\begin{array}{l}10-17 \text { on } \\
\text { each side }\end{array}$ & $\begin{array}{l}14-21 \text { on } \\
\text { each side }\end{array}$ \\
\hline Embryophore diameter & $32-36$ & $22-29 *$ & $25^{*}$ & 27-30 collapsed & $37-40 *$ & $13-14$ & $18-23$ \\
\hline Oncosphere diameter & $12-13$ & $11-15^{*}$ & $13-15^{*}$ & $13 *$ & $11-12 *$ & $11-12$ & $12-18$ \\
\hline No. eggs in cluster & $3-5$ & $7-9$ & $9-14$ & no cluster & no cluster & no cluster & no cluster \\
\hline & present & present & present & not visible & present & absent & absent \\
\hline Type of uterine formation & 1 & 1 & 1 & 1 & 1 & 2 & 2 \\
\hline
\end{tabular}

${ }^{1}$ Earlier name: Ophiotaenia hylae Johnston, 1912; without star-observations made on type materials by the present authors; $*$ data from the original descriptions; Abbreviations: OV = percentage of the width of the ovary in relation to the width of the proglottis; PC = percent of the length of cirrussac in relation to the width of the proglottis; $\mathrm{PP}=$ position of the genital pore (cirrus pore) as $\%$ of the proglottis length; $\mathrm{SL}=$ egg supplementary layer.

\section{Australotaenia grobeli $\mathrm{sp} . \mathrm{n}$.}

Figs. $39-55$

Description (after de Chambrier 2004, modified): Proteocephalidea, Proteocephalidae, Acanthotaeniinae. Testes, ovary and uterine diverticula in medulla, uterine stem cortical. Strobila acraspedote, anapolytic, up to $100 \mathrm{~mm}$ long. Tegument thick and wrinkled in mature proglottides. Numerous small dorsoventral muscles present. Scolex 245-420 $(n=6, x=320)$ wide. Suckers spherical, $100-140$ in diameter $(n=20)$ (Figs. 39-43, 50), covered with dense capilliform filitriches and coniform and gladiate spinitriches (Figs. 46-48). Apical organ spherical, $70-100$ in diameter, covered with small dense capilliform filitriches and coniform spinitriches (Figs. 44, 45). Proliferation zone $200-360$ wide, covered with gladiate spinitriches (Fig. 49). Longitudinal internal musculature well developed, formed by 4-5 large bundles of fibres on both dorsal and ventral sides, missing on lateral sides of body (Fig. 51-54). Ventral and dorsal osmoregulatory canals situated between vitelline follicles and testes (Fig. 52), surrounded by longitudinal muscles, crossing cirrus-sac at its middle part. Ventral canals twice as wide as dorsal canals, with numerous narrow secondary canals directed externally (Fig. 52). Genital pores alternating irregularly, opening between $46 \%$ and $57 \%(n=17, C V=6 \%)$ of proglottis length. Genital atrium deep.

Testes 46-76 in number $(\mathrm{x}=59, \mathrm{n}=30, \mathrm{CV}=14 \%$, 14-26 preporal, 6-18 postporal and 23-44 aporal) in two dorsal fields, with tendency to converge anteriorly and posteriorly, in one or two layers, not reaching laterally to vitelline follicles (Fig. 52), 50-80 in diameter, degenerated in gravid proglottides. Vas deferens coiled, between base of cirrus-sac and median part of proglottis, often extending beyond body midline in mature and premature proglottides, extending anteriorly. Cirrus-sac pyriform, thick-walled, 175-215 long, $\mathrm{PC}=27-33 \% \quad(\mathrm{x}=29 \%$, $\mathrm{n}=17, \mathrm{CV}=4 \%$ ). Cirrus occupying up to $85 \%$ of cirrussac length.

Vagina anterior $(60 \%)$ or posterior $(40 \%)(n=40)$ to cirrus-sac, with a subterminal vaginal sphincter (Figs. 51, 52). When vagina anterior, it passes ventral to cirrus-sac. Mehlis' glands 45-65 in diameter. Ovary bilobed, medullary, follicular, with dorsal outgrowths (Figs. 52, 53). $\mathrm{OV}=55-63 \%(\mathrm{x}=60 \%, \mathrm{n}=17, \mathrm{CV}=3 \%)$ (Figs. 52, 53). Vitelline follicles in two lateral bands, occupying $87-$ $91 \%$ of proglottis length porally and $86-88 \%$ aporally.

Primordium of uterine stem cortical, already present in immature proglottides, with diverticula in medulla. 

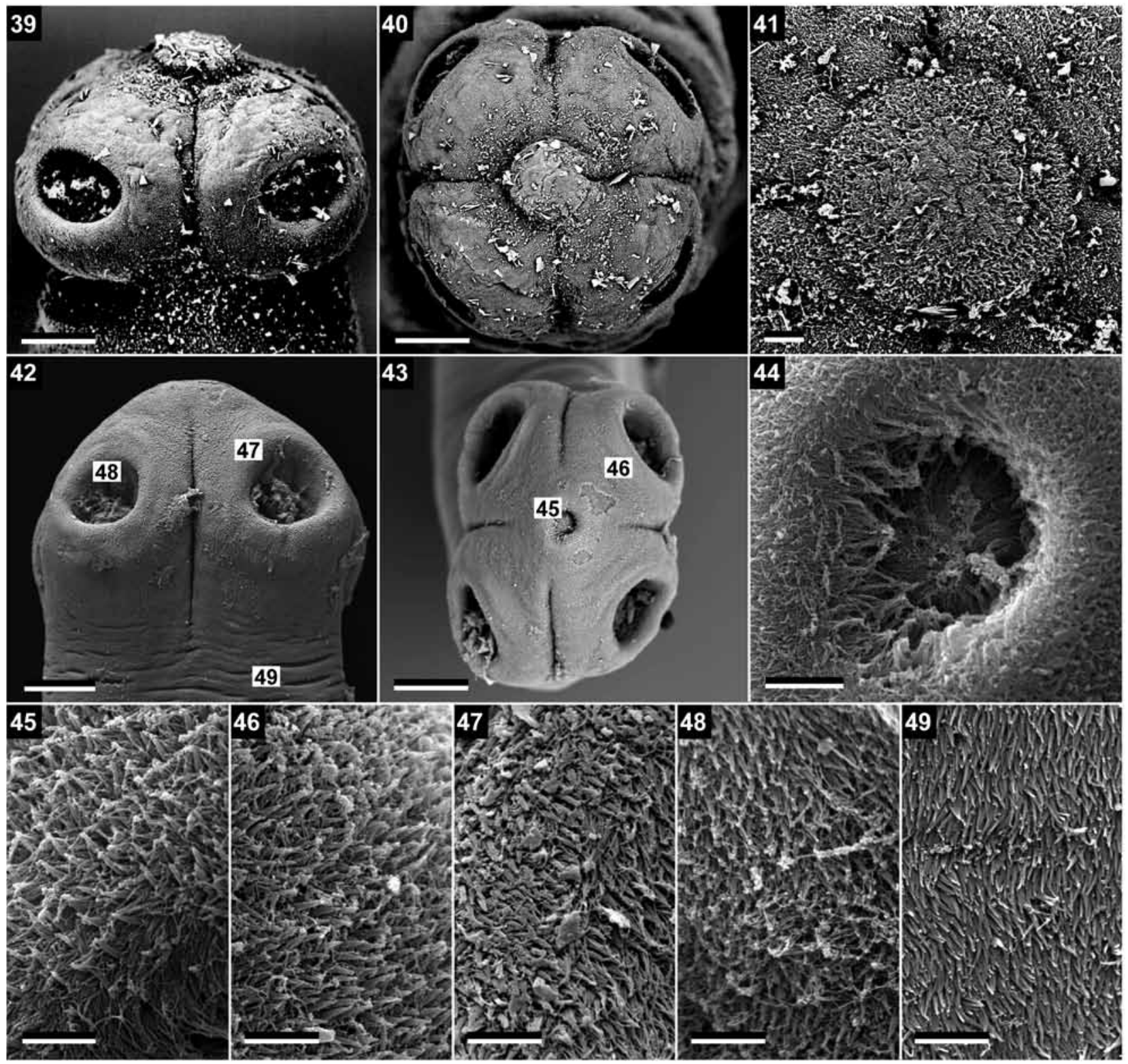

Figs. 39-49. Australotaenia grobeli gen. et sp. n. Paratype (BMNH 1968.4.19.1-15). Scanning electron micrographs. Fig. 39. Scolex, lateral view, note the everted apical organ. Fig. 40. Scolex, apical view. Fig. 41. Detail of the apical organ, apical view. Fig. 42. Scolex, lateral view. Note: small numbers correspond to the figures showing higher magnification images of these surfaces. Fig. 43. Scolex, apical view; apical organ invaginated. Fig. 44. Detail of the apical organ showing long capilliform filitriches, apical view. Fig. 45. Capilliform filitriches and coniform spinitriches on the margin of the apical organ. Fig. 46. Capilliform filitriches and coniform spinitriches on the external surface of suckers. Fig. 47. Capilliform filitriches and gladiate spinitriches on the marginal surface of suckers. Fig. 48. Capilliform filitriches and coniform spinitriches on the internal surface of suckers. Fig. 49. Capilliform filitriches and gladiate spinitriches on the surface of the proliferation zone. Scale bars: Figs. 39, 40, 42, $43=50 \mu \mathrm{m}$; Figs. $41,44=10 \mu \mathrm{m}$; Figs. $45-49=3 \mu \mathrm{m}$.

Formation of uterus of Type 2 sensu de Chambrier et al. (2004); 14-21 uterine branches in each side. Eggs measured in distilled water: embryophore 18-23 in diameter, outer envelope up to 55 in diameter (Fig. 55), with oncosphere 12-18 in diameter. Embryonic hooks 5-9 long.

Type host: Litoria moorei (Copland) (Amphibia: Hylidae). Type locality: Neighbourhood of Perth (Cannington and Darlington), W.A., Australia.
Type material: Holotype, 1 whole mount preparation, SAM 21402, Darlington, W.A., 12.11.1980. Paratypes: BMNH 1968.4.19.1-15, 10 slides of whole mounted specimens, cross-sections and material in alcohol (from where the SEM data come from), ex Litoria moorei, Cannington, Western Australia, 17.04.1966, leg. W.G. Inglis.

Site of infestation: Intestine.

Etymology: The new species is named in honour of Yan Grobel (Geneva). 

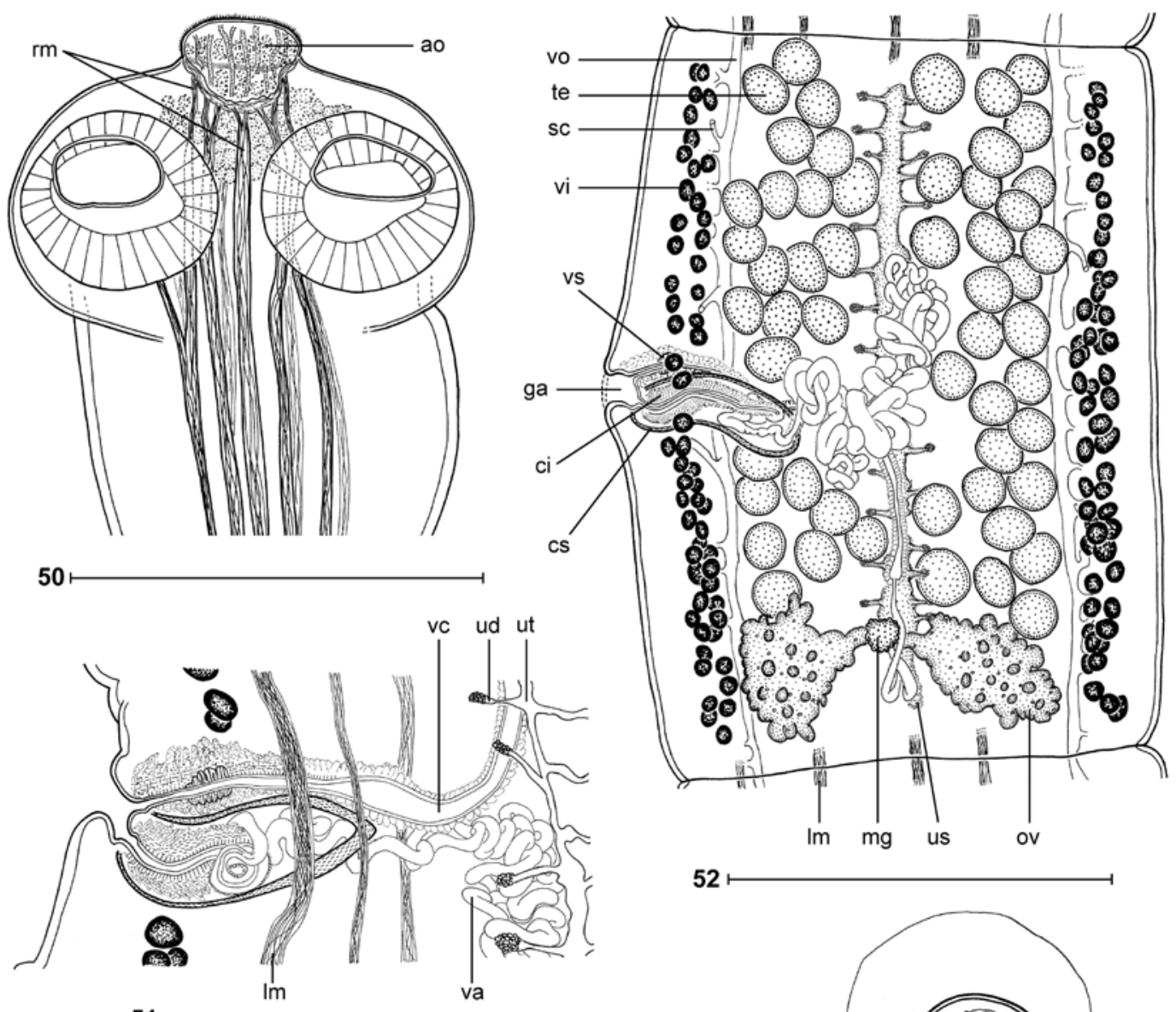

51
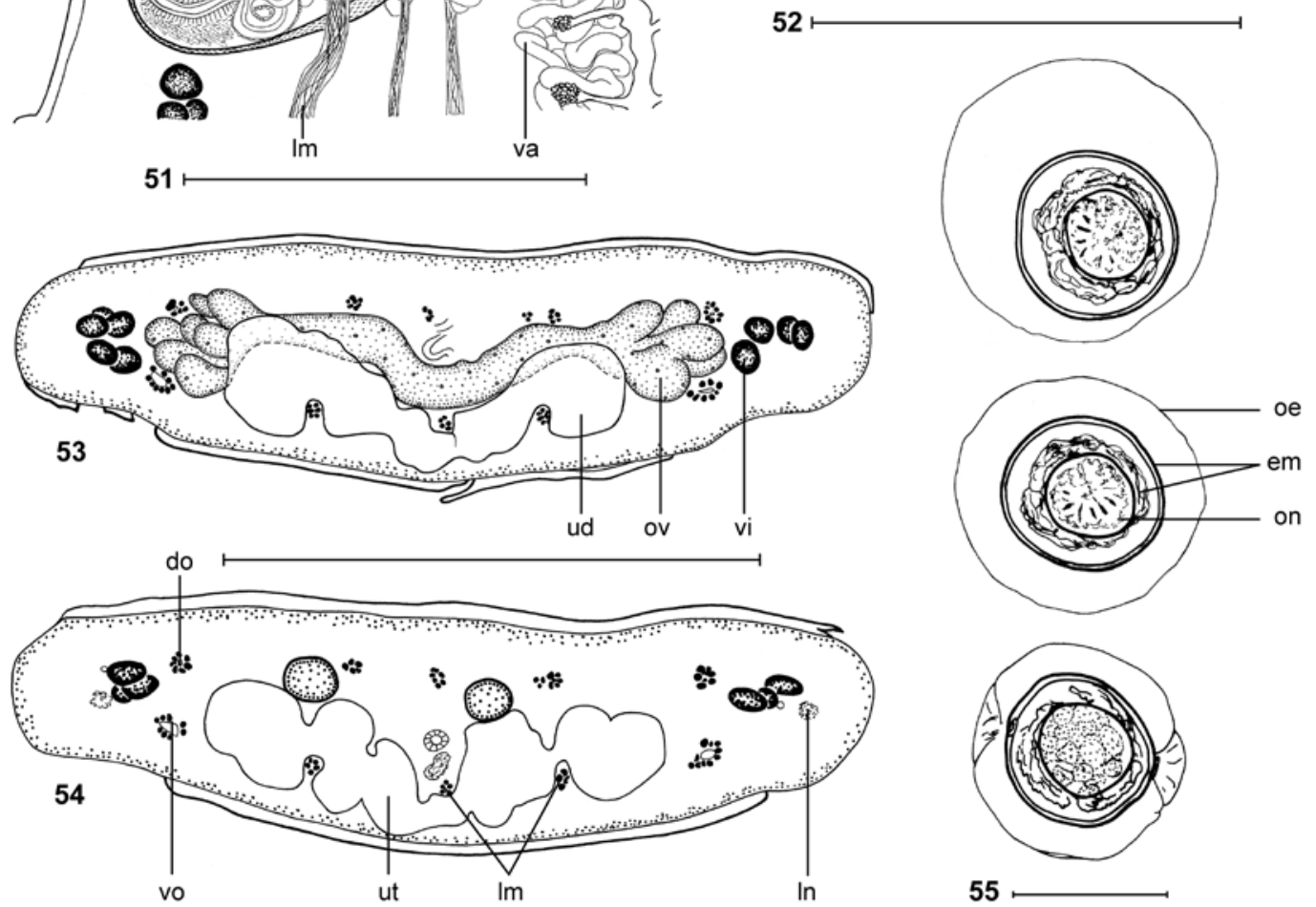

55

Figs. 50-55. Australotaenia grobeli gen. et sp. n. Paratypes BMNH 1968.4.19.1-15, Figs. 50, 51, 53, 54; Holotype SAM 21402, Fig. 52. Fig. 50. Scolex, dorsoventral view. Fig. 51. Vagina and cirrus-sac region, ventral view. Fig. 52. Mature proglottis, dorsal view (according to de Chambrier 2004, modified). Figs. 53, 54. Cross-sections at the level of the ovary and the posterior part of pregravid proglottis, respectively. Fig. 55. Eggs in distilled water. Abbreviations: ao - apical organ; ci - cirrus; cs - cirrus-sac; do - dorsal osmoregulatory canal; em - bilayered embryophore; ga - genital atrium; $1 \mathrm{~m}$ - internal longitudinal musculature; $\ln$ - longitudinal nerve; $\mathrm{mg}$ - Mehlis' glands; oe - outer envelope; on - oncosphere; ov - ovary; rm - retractor muscles; sc - secondary canal; te - testes; ud - uterine diverticula; us - uterine stem; ut - uterus; va - vas deferens; vc - vaginal canal; vi - vitelline follicles; vo - ventral osmoregulatory canal; vs - vaginal sphincter. Scale bars: Figs. 50, $51=250 \mu \mathrm{m}$; Figs. 52-54 = 500 $\mu \mathrm{m} ;$ Fig. $55=20 \mu \mathrm{m}$. 
Remarks. De Chambrier (2004) reported Ophiotaenia sp., a parasite of the Australian frog Litoria moorei from the surroundings of Perth. It has a scolex very similar to A. hylae but differs in several characteristics (see below). Originally, this species was not named, because the material was considered insufficient. Since a new material from the BMNH was obtained for the present study, this cestode could be formally described herein.

Australotaenia grobeli differs from A. hylae by the number of testes (46-76 versus 74-106 in A. hylae), the cirrus-sac length to width of proglottis ratio (27-33\% versus $17-19 \%$ in $A$. hylae) and the ovary width to proglottis width ratio (55-63\% versus $68-71 \%$ in $A$. hylae) (de Chambrier 2004) (Table 1).

Acknowledgements. We are indebted to Lester Cannon (Brisbane), Ian Whittington and Leslie Chisholm (Adelaide) for loan of the type material, David I. Gibson, Eileen Harris (London) and David Spratt (Canberra) for loan of comparative material; Susan
Lim Lee-Hong (Kuala Lumpur), Ian Beveridge (Melbourne), Matthew Bonnett (Adelaide), Lester Cannon (Brisbane), Peter Canty (Adelaide), Craig Eddie (Roma, Queensland), and Andrew Kelly (Brisbane) for their contribution in providing samples, help or permits for this work. We are grateful to Tomás Scholz (České Budějovice), who provided fruitful comments on earlier versions of the manuscript, Boyko Georgiev and an anonymous referee for helpful suggestions, Janik Pralong for technical assistance, André Piuz for scanning electron micrographs, and Florence Marteau and Gilles Roth (all Geneva) for finalising the drawings. The first author thanks Juan Montoya (Geneva) for his warm and constant support during her Master thesis. This project was supported in part by the National Sciences Foundation (PBI award Nos. 0818696 and 0818823 ). The author is deeply indebted to the Donation Georges et Antoine Claraz for supporting this study. Australian permits: Victoria permit No. 10002292, File No. FF380381; Queensland permit No. WWISP01411603; South Australia Adelaide, project 25/2003, permit No. M24506 2.

\section{REFERENCES}

Ammann M., De Chambrier A. 2008: Ophiotaenia gilberti sp. n. (Eucestoda: Proteocephalidea), a parasite of Thamnodynastes pallidus (Serpentes: Colubridae) from Paraguay. Rev. Suisse Zool. 115: 541-551.

Beveridge I. 2003: Phylogenetic relationships of Anoplotaenia dasyuri (Cestoda) from dasyurid marsupials, with observations on uterine development in Cyclophyllideans. In: C. Combes and J. Jourdane (Eds.), Taxonomie, Écologie et Évolution des Métazoaires Parasites. Livre-hommage à Louis Euzet. Vol. 1. Presses Universitaires de Perpignan, Perpignan, pp. 47-66.

Cañeda-Guzmán I.C., de Chambrier A., Scholz T. 2001: Thaumasioscolex didelphidis n. gen. and n. sp. (Eucestoda: Proteocephalidae) from the black-eared opossum Didelphis marsupialis from Mexico, the first proteocephalidean tapeworm from a mammal. J. Parasitol. 87: 639-647.

Chervy L. 2009: Unified terminology for cestode microtriches: a proposal from the International Workshops on Cestode Systematics in 2002-2008. Folia Parasitol. 56: 199-230.

Conn D.B., ŚWiderski Z. 2008: A standardised terminology of the embryonic envelopes and associated developmental stages of tapeworms (Platyhelminthes: Cestoda). Folia Parasitol. 55: $42-52$.

Coquille S.C., De Chambrier A. 2008: Cairaella henrii gen. n., sp. n., a parasite of Norops trachyderma (Polychrotidae), and Ophiotaenia nicoleae sp. n. (Eucestoda: Proteocephalidea), a parasite of Thecadactylus rapicauda (Gekkonidae), in Ecuador. Folia Parasitol. 55: 197-206.

De ChAMBrier A. 1987: Vaucheriella bicheti n. gen., n. sp. (Cestoda: Monticelliidae, Zygobothriinae) parasite de Tropidophis cf. taczanowskyi (Steindachner, 1880) (Serpentes: Tropidophidae) des Andes équatoriennes. Rev. Suisse Zool. 94: 829-840.

De Chambrier A. 2001: A new tapeworm from the Amazon, Amazotaenia yvettae n. gen., n. sp. (Eucestoda: Proteocephalidea) from the siluriform fishes Brachyplatystoma filamentosum and B. vaillanti (Pimelodidae). Rev. Suisse Zool. 108: 303-316.

De Chambrier A. 2004: Redescription of Ophiotaenia hylae Johnston, 1912 (Eucestoda: Proteocephalidea), parasite of Litoria aurea (Amphibia: Hylidae) from Australia. Rev. Suisse Zool. 111: $371-380$.
De Chambrier A. 2006: Redescription of Kapsulotaenia sandgroundi (Carter, 1943), a parasite of Varanus komodoensis (Varanoidea: Varanidae) from Komodo Island, Indonesia. Syst. Parasitol. 63: 83-93.

de Chambrier A., Al-Kallak S., Mariaux J. 2003: A new tapeworm Postgangesia inarmata sp. n. (Eucestoda: Proteocephalidea: Gangesiinae), parasite of Silurus glanis (Siluriformes) from Iraq and some considerations on Gangesiinae. Syst. Parasitol. 55: 199-209.

de Chambrier A., Ammann M., Scholz T. 2010: First species of Ophiotaenia (Cestoda: Proteocephalidea) from Madagascar: Ophiotaenia georgievi sp. n., a parasite of the endemic snake Leioheterodon geayi (Colubridae). Folia Parasitol. 57: 197-205.

De Chambrier A., Scholz T. 2005: Redescription of Houssayela sudobim (Eucestoda: Proteocephalidea), a parasite of Pseudoplatystoma fasciatum (Siluriformes) from the Amazon River. Syst. Parasitol. 62: 161-169.

de Chambrier A., Takemoto R.M., Pavanelli G.C. 2006: Nomimoscolex pertierrae n. sp. (Eucestoda: Proteocephalidea), a parasite of Pseudoplatystoma corruscans (Siluriformes: Pimelodidae) in Brazil and redescription of Nomimoscolex sudobim Woodland, 1935, a parasite of P. fasciatum. Syst. Parasitol. 64: 191-202.

De Chambrier A., Vaucher C. 1992: Nomimoscolex touzeti n. sp. (Cestoda), a parasite of Ceratophrys cornuta (L.): first record of a Monticelliidae in an amphibian host. Mem. Inst. Oswaldo Cruz 87: 61-67.

de Chambrier A., Vaucher C. 1997: Révision des cestodes (Monticelliidae) décrits par Woodland (1934) chez Brachyplatystoma filamentosum avec redéfinition des genres Endorchis Woodland, 1934 et Nomimoscolex Woodland, 1934. Syst. Parasitol. 37: 219-233.

de Chambrier A., Vaucher C. 1999: Proteocephalidae et Monticelliidae (Eucestoda: Proteocephalidea) parasites de poissons d'eau douce du Paraguay avec descriptions d'un genre nouveau et de dix espèces nouvelles. Rev. Suisse Zool. 106: 165-240.

de Chambrier A., Vaucher C., Renaud F. 1992: Etude des caractères morpho-anatomiques et des flux géniques chez quatre Proteocephalus (Cestoda: Proteocephalidae) parasites de Both- 
rops jararaca au Brésil et description de trois espèces nouvelles. Syst. Parasitol. 23: 141-156.

de Chambrier A., Zehnder M.P., Vaucher C., Mariaux J. 2004: The evolution of the Proteocephalidea (Platyhelminthes, Eucestoda) based on an enlarged molecular phylogeny, with comments on their uterine development. Syst. Parasitol. 57: $159-171$.

FreZE V.I. 1965: [Proteocephalata in Fish, Amphibians and Reptiles]. Essentials of Cestodology. Vol. V. Nauka, Moscow, 538 pp. (In Russian. English translation, Israel Program of Scientific Translation, 1969, Cat. No. 1853. v + 597 pp.).

FreZE V.I. 1963: [Convergent formation of the rostellum in two branches of Proteocephalata; revision of subfamilies Gangesiinae Mola, 1929 and Acanthotaeniinae Freze, 1963 (Cestoda, Proteocephalata)]. Gel'minty cheloveka, zhivotnykh i sel'skokhozyaistvennykh rastenii (k 85-letiyu Akademika K.I. Skrjabina), pp. 150-155. (In Russian).

Hoberg E.P., Jones A., Bray R.A. 1999: Phylogenetic analysis among the families of the Cyclophyllidea (Eucestoda) based on comparative morphology, with new hypotheses for co-evolution in vertebrates. Syst. Parasitol. 42: 51-73.

Johnston T.H. 1911: Proteocephalus gallardi, a new cestode from the black snake. Ann. Queensl. Mus. 10: 175-181.

Johnston T.H. 1912: A census of Australian reptilian Entozoa. Proc. R. Soc. Queensl. 23: 233-249.

Johnston T.H. 1913: Notes of some Entozoa. Proc. R. Soc. Queensl. 24: 63-91.

Johnston T.H. 1914: Second report on Cestoda and Acanthocephala. Ann. Trop. Med. Parasitol. 8: 105-112.

Johnston T.H. 1916: Helminthological notes. Mem. Queensl. Mus. 5: 186-196.

von Linstow O. 1903: Drei neue Tänien aus Ceylon. Zentralbl. Bakteriol. Parasitol. 33: 532-535.

Marsella C.M.V., de Chambrier A. 2008: Ophiotaenia alessandrae sp. n. (Eucestoda: Proteocephalidea), a parasite of Hyla boans (Anura: Hylidae) from Ecuador. Rev. Suisse Zool. 115: 553-563.

MegGitt F.J. 1927: Remarks on the cestode families Monticelliidae and Ichthyotaeniidae. Ann. Trop. Med. Parasitol. 21: 69-87.
Nybelin O. 1917: Australischen Cestoden. Results of D.E. Mjoeberg's Swedish scientific expeditions to Australia, 1910-1913. K. svenska Vetensk-Akad. Handl. 52 (14): 1-48.

Pavanelli G.C., Takemoto R.M. 1995: New species of Proteocephalus (Cestoda - Proteocephalidae) parasitic in fishes from the Parana River, Parana, Brazil. Mem. Inst. Oswaldo Cruz 90: 593-596.

Prudhoe S., Bray R.A. 1982: Platyhelminth parasites of the Amphibia. British Museum (Natural History), London, 217 pp.

Rego A.A. 1994: Order Proteocephalidea Mola, 1928. In: L.F. Khalil, A. Jones and R.A. Bray (Eds.), Keys to the Cestode Parasites of Vertebrates. CAB International, Wallingford, pp. 257-293.

SCHмidT G.D. 1986: CRC Handbook of Tapeworm Identification. CRC Press, Boca Raton, Florida, 675 pp.

Scholz T., Hanzeloví V. 1998: Tapeworms of the genus Proteocephalus Weinland, 1858 (Cestoda: Proteocephalidae), parasites of fishes in Europe. Studie AV ČR, 1998, No. 2, 119 pp.

Wardle R.A., McLeod J.A. 1952: The Zoology of Tapeworms. University of Minnesota Press, Minneapolis, $780 \mathrm{pp}$.

Woodland W.N.F. 1934a: On the Amphilaphorchidinae, a new subfamily of proteocephalid cestodes, and Myzophorus admonticellia, gen. and sp. n., parasitic in Pirinampus spp. from the Amazon. Parasitology 26: 141-149.

Woodland W.N.F. 1934b: On some remarkable new cestodes from the Amazon siluroid fish Brachyplatystoma filamentosum (Lichtenstein). Parasitology 26: 268-277.

Woodland W.N.F. 1935a: Additional cestodes from the Amazon siluroids pirarará, dorãd, and sudobím. Proc. Zool. Soc. Lond. 104: 851-862.

WoodLand W.N.F. 1935b: Some more remarkable cestodes from Amazon siluroid fish. Parasitology 27: 207-225.

Zehnder M.P., de Chambrier A., Vaucher C., Mariaux J. 2000: Nomimoscolex suspectus n. sp. (Eucestoda: Proteocephalidea, Zygobothriinae) with morphological and molecular phylogenetic analyses of the genus. Syst. Parasitol. 47: 157-172.

Zehnder M.P., Mariaux J. 1999: Molecular systematic analysis of the order Proteocephalidea (Eucestoda) based on mitochondrial and nuclear rDNA sequences. Int. J. Parasitol. 29: 18411852.

Accepted 2 August 2010 